\title{
The Fate of the Method of 'Paradigms' in Paleobiology
}

\author{
MARTIN J. S. RUDWICK (1) \\ Department of History and Philosophy of Science \\ University of Cambridge \\ Cambridge \\ $U K$ \\ E-mail:mjsr100@cam.ac.uk
}

\begin{abstract}
An earlier article described the mid-twentieth century origins of the method of "paradigms" in paleobiology, as a way of making testable hypotheses about the functional morphology of extinct organisms. The present article describes the use of "paradigms" through the 1970s and, briefly, to the end of the century. After I had proposed the paradigm method to help interpret the ecological history of brachiopods, my students developed it in relation to that and other invertebrate phyla, notably in Euan Clarkson's analysis of vision in trilobites. David Raup's computer-aided "theoretical morphology" was then combined with my functional or adaptive emphasis, in Adolf Seilacher's tripartite "constructional morphology." Stephen Jay Gould, who had strongly endorsed the method, later switched to criticizing the "adaptationist program" he claimed it embodied. Although the explicit use of paradigms in paleobiology had declined by the end of the century, the method was tacitly subsumed into functional morphology as "biomechanics."
\end{abstract}

Keywords: Paleobiology, Functional morphology, Paradigm, Stephen Jay Gould, David Raup, Adolf Seilacher, Martin Rudwick

\section{Introduction}

A previous article (Rudwick, 2017) summarized the history of research in the early to mid-twentieth century on the functional morphology of extinct organisms, in relation to the concept of Paläobiologie. This kind of paleontology was developed, initially in the German-speaking world, in contrast to the dominant worldwide practice of paleontology as a science centred on taxonomy and oriented primarily towards serving the needs of stratigraphical geology. Within "paleobiology" my article focused on the kind of functional inference that I proposed in 1961 as the 
method of "paradigms," adopting this then unusual word just 1 year before Thomas Kuhn (1962) famously gave it much wider currency with a quite different meaning. The article summarized a few of the "worked exemplars" that I published during the 1960s to illustrate the paradigm method in action, and to argue that it enabled rival functional interpretations of specific morphological features - and hence of the whole "ways of life" of extinct organisms - to be tested for their relative plausibility (e.g., Rudwick, 1961, 1964a, 1965). These case-studies were all drawn from the fossil record of brachiopods, a major phylum for invertebrate paleontologists although often dismissed as "minor" by those biologists who only study living organisms. However, in explaining the paradigm method to philosophers of science I had argued that it had epistemological implications for functional inferences on fossil organisms of all kinds, and that it was therefore relevant to the interpretation of the history of life as a whole (Rudwick, 1964b).

The present article continues this narrative account of the method of paradigms in paleobiology through the 1970s and beyond, in the wider contexts of functional morphology and the evolutionary interpretation of the fossil record. I shall describe how, and suggest why, the method met with such a mixed reception, ranging from enthusiastic adoption through indifference to outright rejection. I shall trace its ambivalent fate in paleobiological practice, and outline its role in the history of evolutionary theorizing in the late twentieth century.

The history of the paradigm concept in paleontology illustrates the diversity of the factors that may impinge on this kind of scientific research. These ranged from the material and interpersonal, such as the access that particular scientists were given or not given to specific collections of fossil specimens, to the most abstractly conceptual, such as the unspoken fear that any use of the language of "organic design" in biology (or paleobiology) might open the door to some variety of deistic metaphysics or even to "intelligent design" creationism.

I myself (Martin Rudwick 1932-) ceased after 1971 to contribute directly to this paleontological research, having in 1967 moved my main field of teaching and research into the history of the sciences that until then I had been practicing professionally. In the present article the autobiographical element is therefore less pronounced than in the previous one; but I will repeat here that it is not my intention to use these articles to rehabilitate, vindicate or celebrate my own earlier research. My aim is simply to use the evidence of my publications and those of other paleontologists, supplemented by a few unpublished sources and my personal recollections, to reconstruct a significant phase in the 
twentieth-century history of the science of evolutionary paleontology. The focus here is, without apology, on work that was directly or indirectly related to my own and my students' contributions to this research; but I hope this article may be useful as a primary source for any historians (or paleontologists) who want to explore the history of this kind of science more extensively and in greater depth than has been feasible here. Certainly the history of paleontology in the twentieth century is a field of research that deserves much greater scholarly attention.

\section{Paradigms and the History of Life}

My earlier research on fossils was focused, as just mentioned, on developing a method by which rival functional interpretations of specific morphological features of extinct organisms could be tested, with the hope of undercutting the then common criticism that functional interpretations of fossils were intrinsically speculative and therefore almost worthless. But my intention from the start was that any such interpretations should contribute to the reconstruction of the "ways of life" of whole organisms, and hence to the interpretation of the adaptive evolution of the groups to which they had belonged. Following this policy, my later research, much of it carried out jointly with my former student Richard Cowen (1940-), had embedded our functional reconstructions of specific brachiopods within the evolutionary history of the whole phylum (as summarized in Rudwick, 1970), suggesting for example their implications for contentious issues such as adaptive radiations, parallel evolution, convergence, and mass extinctions.

The last of these was particularly controversial at this time (more than a decade before the headlines were hit by the melodramatic claim that an asteroid might have hit the Earth and wiped out the dinosaurs). Any suggestion of mass extinctions was widely rejected as a throwback to an outworn and unscientific "catastrophism," and the alleged evidence for such events was dismissed as the product of a highly imperfect fossil record. Nevertheless, Cowen and I, and just a few of our elders and betters, were particularly impressed by the magnitude of the apparent mass extinction at or around the end of the Permian period (and of the Paleozoic era). More specifically, we noted how it seemed to have eliminated some of the most intriguing and perhaps most "promising" innovations ever developed by brachiopods in the course of their evolution. Of these, the peculiar morphology of Prorichthofenia, serving a putatively unusual feeding mechanism (Rudwick, 1961), might 
have been just one. Others were suggested by the equally aberrant morphologies of some other Permian brachiopods known from many localities scattered around the world. The abundant and exceptionally well-preserved specimens from Texas, a few of which I had been able to use for my study of Prorichthofenia, were being prepared for publication by G. Arthur Cooper (1902-2000) and Richard Grant (1927-1995) in Washington D.C., and were not readily available to other paleontologists. Alternative sources were, for example, specimens from the Salt Range in Pakistan or, more accessibly, those collected since the late nineteenth century in the Sosio valley in Sicily. Our own fieldwork in Sicily in 1966 yielded few new specimens, but the Italian university museums in which earlier finds had been deposited provided plenty of quite well-preserved material for our review of several aberrant brachiopod genera, and for our functional interpretations of correspondingly aberrant modes of life.

In particular, the Sosio specimens seemed to confirm my earlier interpretation of Prorichthofenia and related "richthofeniids" from Texas: namely, that a vigorous "flapping" action without parallel among living brachiopods, though somewhat analogous to the pumping action of living septibranch molluscs, could have brought them unusual kinds of floating food (Rudwick, 1961). The Sicilian fossils also became the basis for our interpretation of the quite different - but equally peculiar - morphology of Lyttonia (the broad generic name given at the time) and related "lyttoniids." In these aberrant brachiopods, as in richthofeniids, the shelly ventral valve is hollow or even conical, and a very thin dorsal valve is recessed within it. But the lyttoniid dorsal valve, unlike the trapdoor-like dorsal valve of richthofeniids, is large and complex, being deeply divided into many lateral lobes separated by narrow slits. The British paleontologist Alwyn Williams (1921-2004) had inferred, by analogy with some living brachiopods, that the "lophophore" or suspension-feeding organ of lyttoniids was of multilobed or "ptycholophe" form, with its very long axis running all around the edges of these shelly lobes (Williams, 1953). Cowen and I developed this into a functional reconstruction of a possible "rhythmic-flow" mechanism partially analogous to that attributed to richthofeniids; or, less conjecturally, perhaps a "steady-flow" filtering mechanism broadly comparable to the suspension-feeding operated by all living brachiopods as well as by many other unrelated organisms such as bivalve molluscs and ascidians (Figure 1).

These and several other peculiar Sosio brachiopods were analysed functionally in a densely illustrated monograph that we published in a 

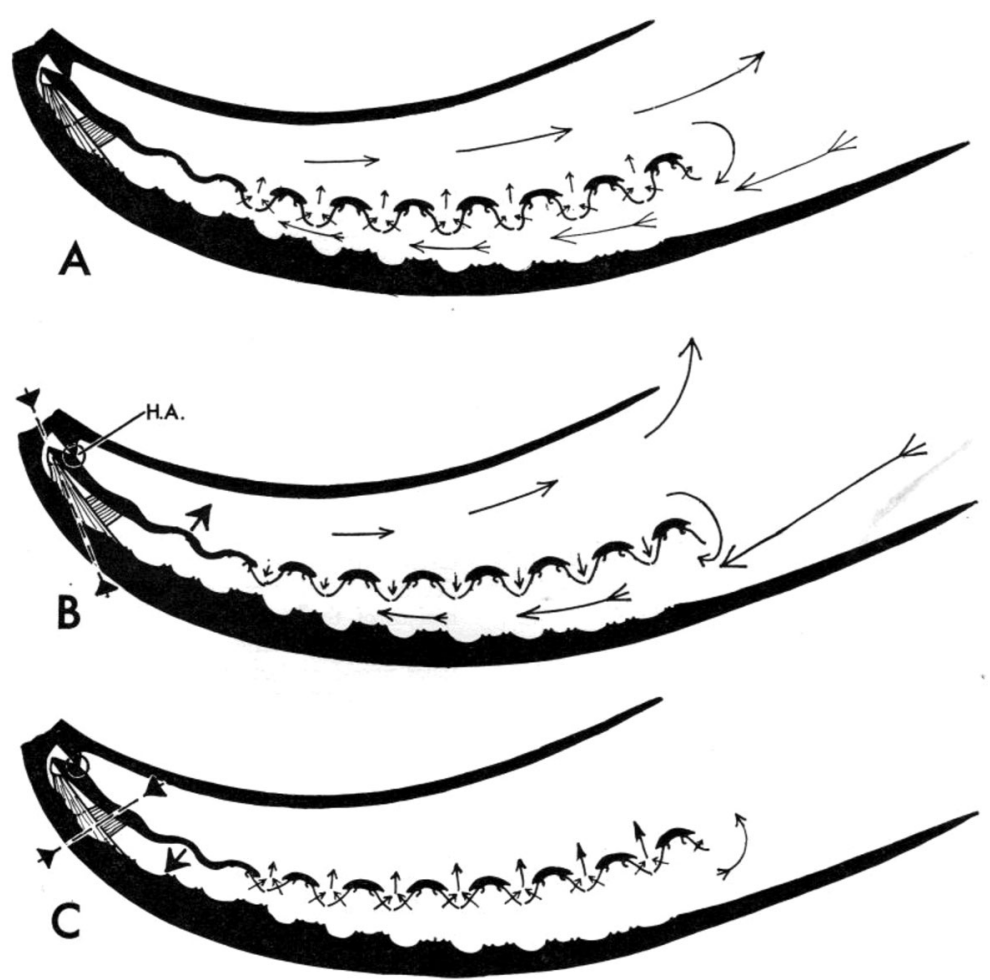

Figure 1. "Interpretation of possible feeding mechanisms of Sicilian 'Lyttonia", showing in section the many lateral lobes of the large but delicate dorsal valve recessed within the conical ventral valve, reconstructed with a lophophore looping all round its edge (Rudwick and Cowen, 1968, Text-fig. 21). " $A$ " shows a possible "steady-flow" suspension-feeding system, with the interior of the ventral valve divided into inhalant and exhalant chambers, and a fair degree of functional efficiency except for some unavoidable recycling around the anterior edge (right) of the dorsal valve. " $B$ " and " $C$ " illustrate a more conjectural "rhythmic-flow" mechanism, in which the dorsal valve rose, perhaps quite slowly, drawing unfiltered water into the lower chamber, followed by the lowering of the dorsal valve and the filtration - perhaps forced filtration - of the water through the lophophore covering the slits between its lobes. (The size and delicacy of the dorsal valve, and the relative weakness of the hinge mechanism and of the muscles, as judged by their attachments on the shell, suggested that any such rhythmic-flow mechanism was unlikely to have been the kind of rapid "flapping" that we inferred for richthofeniids). The usual thin mantle tissue must have been permanently exposed over the whole interior of the ventral valve, far beyond the edges of the dorsal valve: Cowen (1970) later suggested that this tissue might have harbored symbiotic zooxanthellae, as in the living "giant clam" Tridacna common on coral reefs 
leading Italian paleontological journal (Rudwick and Cowen, 1968). We also included some comments on the environmental and climatic implications of what we interpreted as a possibly tropical reef environment. But such questions of paleoecology, paleoclimatology and paleogeography were touched on only briefly, because at this time the underlying issues of continental mobilism (commonly but misleadingly called "drift") and plate tectonics were still unsettled and highly controversial among geologists and geophysicists. Indeed the specific case of the worldwide Permian marine faunas, including prominently their aberrant brachiopods, had recently been reviewed with almost no reference to the possibility of radically changed latitudes or continental positions (Stehli, 1964). On the other hand Cowen and I did refer to the opinion - then equally common among paleontologists - that in reality there had not been any mass extinction event around the end of the Permian period, and that any appearance to the contrary was merely due to the imperfection of the fossil record. Noting the aberrant but "promising" features of many of the highly diverse Sosio brachiopods, we commented that "Such innovations as these might have been expected to lead to new phases of adaptive radiation, but instead they were all eliminated," and, by geological standards, suddenly. As we concluded somewhat tartly, "This requires to be explained, and not merely explained away" (Rudwick and Cowen, 1968, p. 172).

Around the same time I tried to put the strange Permian lyttoniids into a wider evolutionary context, by analyzing the small lyttoniid Poikilosakos of Pennsylvanian (late Carboniferous) age. This had long been regarded as the likely ancestor of all the later and more elaborate Permian forms. I interpreted it in a way that connected it functionally both to them and to its own likely ancestors among still earlier and less aberrant brachiopods (Rudwick, 1971). This paper, which was my last contribution to paleobiology, was eventually published in the Festschrift that honored Cooper's long and distinguished career as a paleontologist (Dutro, 1971). Cooper had been politely sceptical about my functional interpretations of his beloved brachiopods, but his taxonomic work had been massive in its impact. In 1969 he and Grant published a foretaste of their detailed taxonomic research on the Permian brachiopods from the Glass Mountains (Cooper and Grant, 1969), in the first issue of their institution's significantly titled new journal Smithsonian Contributions to Paleobiology. Yet they made few functional comments on their many newly described and newly named genera and species, and did not mention my interpretation of the richthofeniids even to refute it. Cooper's attitude towards the concept of 
"paleobiology," and that of many other American paleontologists of his generation, remained both ambiguous and ambivalent.

\section{Paleoecology and Functional Morphology}

The method of paradigms was of course an application, within paleontology, of the well established biological tradition of functional morphology, which in turn was related to the broader field of ecology. These were aspects of biological science that in the 1960s were being applied with renewed vigor to fossil organisms: not only in the German cultural region that before the Second World War had seen the lively practice of "Paläobiologie," but also in the "paleobiology" championed during the postwar years by George Simpson (1902-1984) and Norman Newell (1909-2005) in New York (see Sepkoski, 2012, pp. 54-67). James Beerbower's Search for the Past (1960), for example, was a sign of this significant change in the science in America: its author was primarily a zoologist, and in contrast to earlier textbooks of palaeontology his work devoted much of its space to interpreting how fossil organisms might have lived. And it was soon followed by the British palaeontologist Derek Ager's Principles of Paleoecology (1963), subtitled "the study of how and where animals and plants lived in the past." However, as Ager's book showed, much paleoecological work was concerned with reconstructing the environments of the past and the assemblages of organisms that had characterised them ("paleosynecology") rather than with the functional interpretation of the morphologies and adaptations of individual organisms ("paleoautecology"). For example, Ager himself described in a separate paper "The adaptations of Mesozoic brachiopods to different environments," as represented by those preserved in stratigraphical formations of different facies (Ager, 1965); but he did not take the further step of interpreting their varied morphologies in terms of distinctive functions or adaptations. Significantly, this paper was published in the first volume of Palaeogeography Palaeoclimatology Palaeoecology: the cumbersome but informative title of this new journal signaled the recognition of a distinctive cluster of related research problems. It soon became an important outlet for research with global dimensions, as for example in the major study by the British paleontologist Anthony Hallam (1933-) on "The bearing of certain palaeozoogeographic data on continental drift" (Hallam, 1967).

Studies of invertebrate fossils in terms of functional morphology belonged in a more specifically biological cluster of problems. Such 
studies were of course far from being limited at this time to my studies of brachiopods. For example, Klaus-Peter Vogel (1931-) of Tübingen working, significantly, in the German environment of Paläobiologie had interpreted the morphology of the highly aberrant Mesozoic "rudist" molluscs in terms of their "Struktur und Funktion" (Vogel, 1960). Vogel later used my account of suspension-feeding in living brachiopods (Rudwick, 1962) as the homological and analogical key to interpret in functional terms the morphology of some distinctive fossil forms, though without explicit reference to the idea of paradigms. He interpreted the bizarre "key-hole" in the shell of the Jurassic brachiopod Pygope as an efficient outlet for an exhalant water current directed well clear of the inhalant ones, in an exceptionally calm deep-water environment (Vogel, 1966). And Grant, while working with Cooper on the spectacular Permian brachiopods from Texas, offered functional interpretations of various "productide" brachiopods: he suggested that their external shelly spines were diversely adaptive devices, serving in some forms to anchor the shells to the stems of crinoids clear of a soft substrate, or, in others, to make possible an almost infaunal habit by stabilising the shells within a similar muddy substrate (Grant, 1963, 1966, 1968).

During the same years, other paleontologists were exploring similar kinds of interpretation for fossils of quite different phyla. For example the British paleontologist Christopher Paul (1941-), who like Cowen had begun his research at Cambridge, was working on cystoids, an enigmatic and totally extinct group of Paleozoic echinoderms. He published fine studies of the "functional morphology and mode of life" of one particular genus (Paul, 1967), and of the "morphology and function" of some distinctive features of the group (Paul, 1968, 1972). Citing the paradigm method, he noted that these features ("porestructures") "agree closely with the paradigm of an exchange system" and were therefore likely to have been respiratory in function; and that they had evolved "from less to more efficient types," as judged by their progressive approximation to a paradigm that was "assumed to have maximal efficiency within the limits imposed by the materials of which the fossil structure is made" (Paul, 1968, pp. 706-707). This expressed very well the essence of the paradigm method as I had conceived it.

However, the ambivalent or optional role of the paradigm method in the functional interpretation of fossils is illustrated by what was being done by my own graduate students at Cambridge during the 1960s. Cowen, who had become my close collaborator on our research project on the functional evolution of the whole brachiopod phylum, used it 
effectively though tacitly in his own studies of brachiopod morphology, as well as collaborating with me in our functional interpretations of some of the highly aberrant Permian forms. I encouraged two other students to explore, like Paul, the functional interpretation of invertebrate fossils of other phyla. Robert Carter (1942-2015) worked on bivalve molluscs, which in some important features - for example the bivalved shell growing by accretion at the mantle edges - were obviously analogous to brachiopods. In particular, he analysed the morphology of certain fossil oysters (Arctostrea) of Cretaceous age, which during ontogeny had developed strongly zigzag valve edges (Carter, 1968). These zigzags were strikingly similar to those in brachiopods that I had interpreted as protective in function (Rudwick, 1964a), but they were on shells of quite different form. Carter cited my paper and used the terms "paradigm" and "paradigmatic" frequently though without special explanation. But he did not adopt the strictly geometrical analysis that I had used to measure the degree of approximation between my brachiopods' zigzags and those I claimed would be "paradigmatic" for ensuring a uniformly narrow slit (which could have functioned efficiently as a protective device). Instead of adopting that interpretation, Carter argued that his oysters' zigzags were an adaptation that had improved the flow of water in and out of the mantle cavity and on to the gills. I thought this explanation less satisfactory, because it did not exploit the paradigm method's potential for testing alternative functional explanations against one another. (Carter later moved his research into more conventional paleoecology and stratigraphy; late in life

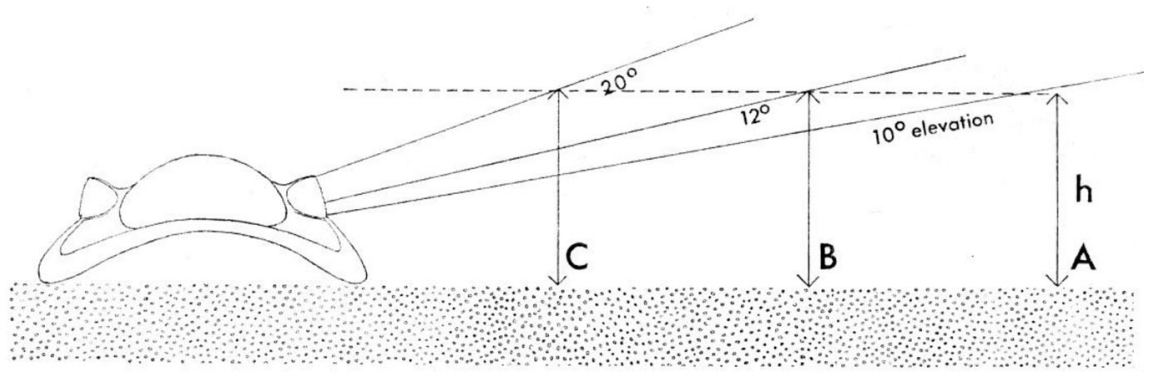

Figure 2. Clarkson's frontal view of the benthonic Silurian trilobite Acaste (the inferred substrate is stippled), showing the vertical range of orientation of the lateral lenses in its compound eyes. "An object of height $h$ approaching the trilobite would not be detected at $A$. At $B$ it would come within the lower part of the visual field, and at $C$ it would be sighted by the uppermost lenses... A conception of the size, speed, and direction of the moving object would be given by the changing pattern" (Clarkson, 1966a, Text-fig. 10, p. 25; by kind permission of Professor Euan Clarkson) 
Figure 3. Clarkson's analysis of the compound eyes of a particular specimen of the Silurian trilobite Dalmanites, showing the array of individual lenses $(d)$ and the vertical $(e)$ and horizontal $(f)$ fields of view given by them: nearly horizontal and all round, with overlaps ahead of and behind the animal. The orientations of the lens axes are plotted stereographically $(a)$, and their angular separation $(b)$ shows the greatest perceptual concentration in a low lateral zone (Clarkson, 1966b, Text-fig. 8; by kind permission of Professor Euan Clarkson)

he became famous - or notorious - in Australia as a prominent "climate change sceptic.")

Of all the research by my students at this time, what gained the most attention among other palaeontologists was that published by Euan Clarkson (1937-) on the eyes of trilobites. Developing an initial suggestion of mine, Clarkson constructed a device for plotting the precise orientations of the relatively large individual lenses in the "schizochroal" compound eyes of some well-preserved trilobites (phacopids and acastids) of Silurian age. He then reconstructed the fields of view that the animals would have had (all round, but usually narrowly horizontal), with a precision and certainty that was derived directly from the threedimensional geometry of their eyes. And from this he inferred the likely function of the eyes - for detecting other benthonic animals, primarily for defense - and the trilobites' general modes of life (Clarkson, 1966a, b). He cited my paper (Rudwick, 1964b) for "the methodology of such functional interpretation[s] of fossil structure," but did not refer explicitly to the idea of paradigms. Nonetheless, his study of trilobite eyes was a superb example of a close approximation between observed structures and those that were clearly paradigmatic for the inferred function of all-round benthonic vision (Figures 2, 3). And while he had no reason or need to refer back to the early history of his science, it is relevant in the present context to note that the all-round vision made possible by many trilobite eyes had already been commented on - with evident astonishment at their superb "organic design" - by Georges Cuvier's younger contemporary and admirer William Buckland, during the great pre-Darwinian flowering of fossil functional morphology in the early nineteenth century (see Rudwick, 2008, pp. 434-435).

From this summary of some of my own students' work it is clear that an explicit use of the paradigm method was not a necessary condition for their functional interpretations of fossil morphologies. Yet my own strong commitment to it may have encouraged them to share my working assumption that any and every fossil structure may have been adapted more or less effectively to some specific function (or to some combination of functions or to some compromise between them), so that it would always be worthwhile to try to investigate what these 

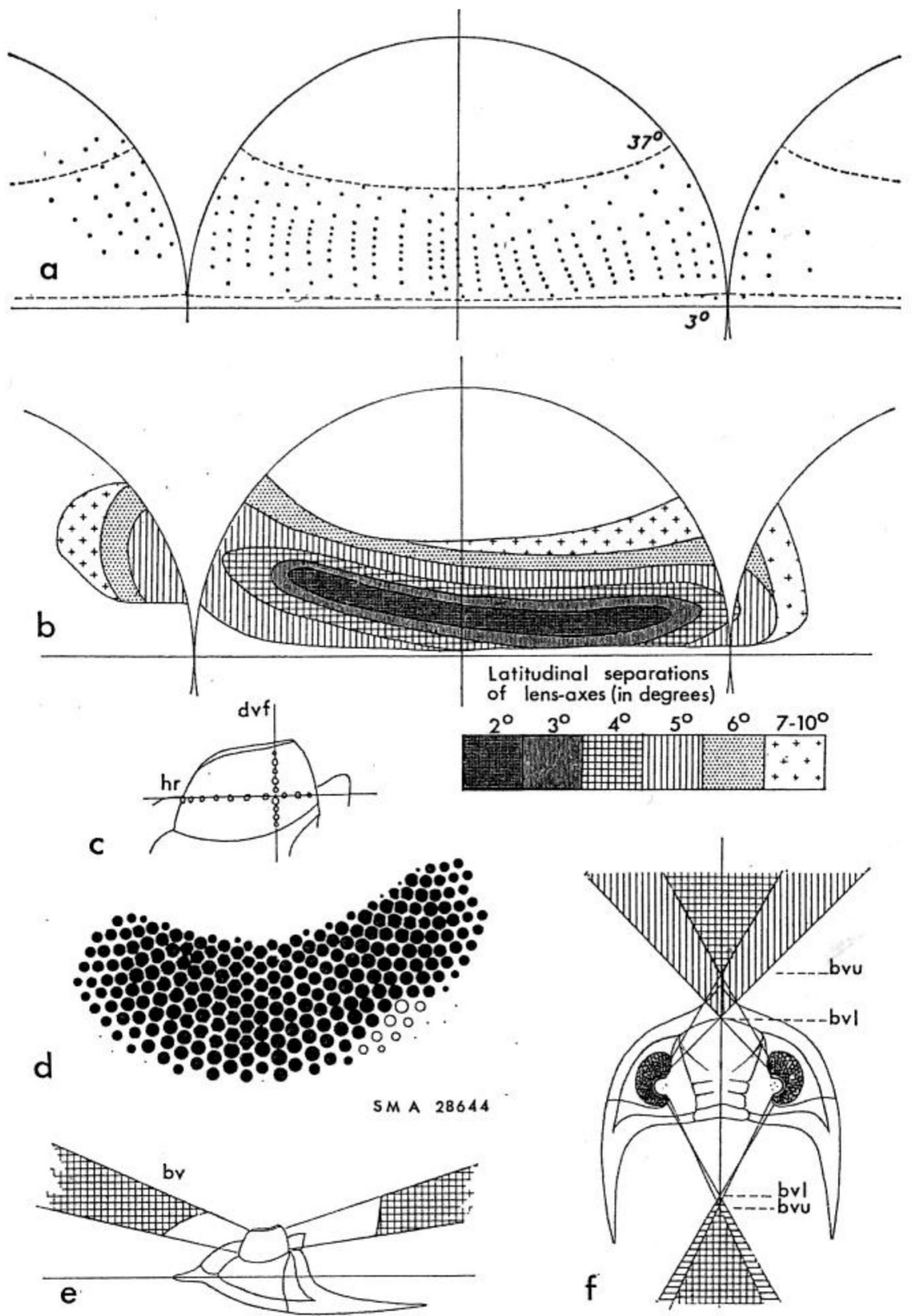
adaptations might have been. Unless one was on the lookout for possible adaptations one would never detect them. To put it more strongly, adaptedness deserved to be a working assumption in any morphological research on fossils; it was unwise, and methodologically unjustified, to set a priori any limits to the functional optimizations that natural selection might have generated in the course of evolution. Conversely, as I had argued (Rudwick, 1964b), it was logically impossible to prove that any fossil structure had had no adaptive advantage, whatever one's view of the power of natural selection.

A fine example of the fruitfulness of this kind of approach, owing nothing (as far as I know) to my work, came from the young American paleontologist Steven Stanley (1941-), whose research at Yale - one of the leading centers for paleontology in the United States at this time interpreted a major feature of the evolutionary history of bivalve molluscs in terms of a crucial morphological innovation (Stanley, 1968). As with Nichols's impressive earlier study of the micro-evolution of the Cretaceous sea-urchin Micraster (Nichols, 1959a, b), Stanley's work did not need the kind of rather abstract analysis represented by the paradigm method, because the functional morphology of his fossils could be interpreted with some confidence in the light of substantial knowledge of their living relatives. Stanley interpreted the greatly enlarged representation of bivalves among post-Paleozoic marine fossils as the record of a major adaptive radiation, which was made possible by the evolution, in certain bivalves, of a partial fusion of the mantle edges. This enhanced these bivalves' suspension-feeding systems by enabling the inhalant and exhalant apertures and water currents to be separated more effectively. But in time it also made possible the further evolution of the fused mantle edges into tubular "siphons," which eventually allowed many of these molluscs to adopt and exploit deeply infaunal modes of life that had not previously been accessible to any bivalve molluscs. Stanley argued that this gave them a major new adaptive advantage: after the apparent crisis at the end of the Paleozoic era (the possible mass extinction at the end of the Permian period), bivalves had not only replaced vanished kinds of brachiopods in many marine environments, but they had been able to go much further in exploiting many more diverse environments than before. 


\section{Theoretical Morphology and Its Functional Implications}

Stanley's research was symptomatic of a growing trend towards integrating studies of living and fossil invertebrates in interpretations of functional morphology, not only for specific organisms but also for the evolutionary histories of the larger groups to which they belonged. My own attempted synthesis of the adaptive evolution of brachiopods, published shortly afterwards and summarizing my joint research with Cowen, was another case in point (Rudwick, 1970). All this functional morphology was, knowingly or not, following in the tradition of earlier research in the nineteenth century, as analyzed in E. S. Russell's classic Form and Function (1916). A related but initially distinct kind of research was inspired by D'Arcy Thompson's equally classic On Growth and Form (1917; 2nd ed. 1942), which had focused attention on the ontogenetic development of morphology, and hence also on its phylogenetic history. Here a sensational new note was struck in the 1960s by the American paleontologist David Raup (1933-2015), then at Johns Hopkins. Raup's spectacular images of "hypothetical snail forms" (Raup, 1962; Raup and Michelson, 1965) - first published in Science and therefore gaining wide attention - were derived from Thompson's analysis of the geometry of "logarithmic" or "equiangular" spiral forms in diverse organisms (Thompson, 1917, pp. 493-586; 1942, pp. 748849); but Raup's were generated by early computers, both analog and digital, which of course had not been available to Thompson or his contemporaries (Figure 4).

Raup developed this work into a concept of "theoretical morphology": he used his computers to generate a matrix of all the shapes
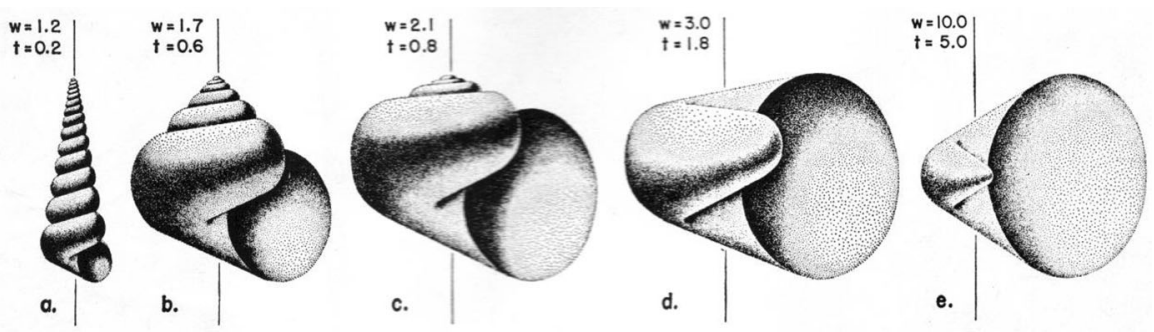

Figure 4. Some of Raup's first published illustrations of "hypothetical snail forms" generated - by a computer program - by varying the parameters of the accretionary growth rates (Raup, 1962, Figure 2; by permission of the American Association for the Advancement of Science). This particular morphological series was just one part of a complex "morphospace" of theoretically possible shell forms, not all of which had ever been developed during the evolutionary history of such shells 
theoretically "possible in this universe of ours" - though he did not use Pantin's (1951) memorable phrase - by varying the basic parameters in the relative rates of accretion at the growing edges of shells. Within this theoretical "morphospace" (as it was later called) he plotted the much more restricted distribution of shapes that had in fact ever developed in the course of the evolution of shells formed by accretionary growth (particularly those of gastropods and cephalopods, but also bivalves and brachiopods). This had obvious functional implications, since many theoretically possible shapes might never have evolved, or only rarely, simply because they were biologically unviable or intrinsically illadapted. Raup's further work on these lines was published among the predominantly taxonomic and stratigraphical papers in the Journal of Paleontology (Raup, 1966, 1967), signaling a belated broadening of the scope of this leading journal in a paleobiological direction (Stanley's 1968 paper was also published there).

It was thus a sign of the times that Raup proposed a symposium on "Paleobiological aspects of growth and development," which was held in New Orleans in 1967 during the annual meeting of the Geological Society of America (Macurda, 1968). The use of the word "paleobiological" in this context was still quite unusual in the anglophone world; and its institutional setting, at least for invertebrates, remained markedly geological rather than biological. At this meeting Raup himself tackled a much more complex case than his snail shells, namely that of the accretionary growth of the mosaic of shelly plates that makes up the shell of a sea-urchin: he harnessed the power of his computers to reconstruct "the ontogeny of the entire plate pattern" (Raup, 1968). This was "theoretical morphology" at its most refined: geometrical analogies with soap bubbles and the cells of honeycombs were prominent in Raup's reasoning; the varied functions of the plates in the life of sea-urchins were not (though of course he was well aware of the functional dimension).

Another American paleobiologist who contributed to this symposium was Stephen Jay Gould (1941-2002), who had just moved to Harvard after studying with Newell at Columbia. Gould was far from being the public celebrity he later became. But he had recently - while still a graduate student - made a striking scientific debut with a major essay on "Allometry and size in ontogeny and phylogeny" (Gould, 1966), published, with the support of the distinguished evolutionary theorist Julian Huxley (1887-1975), in the prestigious Cambridge journal Biological Reviews. Like Raup's work, Gould's was marked by an accent on quantitative issues and mathematical methods, which be- 
came the hallmark of all their later research. At New Orleans Gould used some of his doctoral research on fossil snails from Bermuda to present an allometric analysis of "Ontogeny and the explanation of form." He also used his analysis of ontogeny to indicate, at least briefly, the possible implications of growth and form for functional morphology: among his suggested explanations of evolutionary parallelism were the cases where "the adaptation arises many times because it is the only possible solution to a given [functional] problem" (Gould, 1968, p. 97).

At Raup's suggestion I too was invited to contribute to this symposium; I was the only speaker from outside the United States. It was at New Orleans that I first met Raup and Gould: although I had spent several summer periods in Washington in the preceding years, studying fossil brachiopods in the U.S. National Museum, I had not previously met any of the younger American scientists who were working in strongly paleobiological directions like my own. I used the occasion to develop my earlier brief analysis of the growth and form of brachiopod shells (Rudwick, 1959), but also to integrate it with a further explanation of my method of paradigms (Rudwick, 1964b), covering the functional analysis of the ontogenetic development of brachiopods, and hence also of their likely phylogenies (Rudwick, 1968). While my work was primarily qualitative, I did use the example of lyttoniid morphology to suggest how the growth of the bizarre and strangely variable dorsal valve had been governed during both ontogeny and phylogeny by simple morphogenetic rules; I illustrated this with manually-generated hypothetical forms that replicated real specimens, while recognizing that in principle they, like Raup's, could have been produced by an appropriate computer program, had I been competent to do so. In any case the forms of the dorsal valve could be related to its function in the putative feeding mechanism (Figure 5).

Before publication my paper was sent to be assessed by Grant, Cooper's collaborator and, as already mentioned, the author of papers on the functional interpretation of specific features of some Permian brachiopods; he might have been expected to be more sympathetic than his senior colleague towards such work. But Grant disliked what he regarded as my "polemical style": I had indeed been critical of the failure of most brachiopod specialists to take the implications of accretionary growth, let alone any functional issues, into account in their descriptive and taxonomic work. More seriously, however, while Grant conceded that the paradigm method "has produced some extremely interesting and stimulating results," he dismissed it as no more than commonsense, "with the highly convoluted terminology of 



Figure 5. "Simulated growth of oldhaminoid [lyttoniid] dorsal valve, based upon postulated morphogenetic "rules", and "Simulated abnormal growth" when those "rules" fail locally (Rudwick, 1968, Text-figs. 10, 11). These manually-generated forms simulated real specimens from the Permian of Sicily. Even if the normal growth pattern happened to fail locally, the continued operation of the rules would maintain the uniformity of the lobes and of the slits between them, which might have been functionally essential

"paradigmatic functional analysis" added later as an "encrustation"” (Grant to Macurda [copy to Rudwick, 1968]). (In fact, as outlined in Rudwick, 2017, the idea of paradigms had been prominent in my work 
from the start.) The following year Grant and Cooper, as already mentioned, published a preliminary account of many of their superbly preserved Permian brachiopods from Texas (Cooper and Grant, 1969); but it was purely taxonomic and made little reference to any kind of functional interpretation. It is therefore perhaps not surprising that Gould later told me that research by one of his students, on the functional morphology of one of the bizarre lyttoniid brachiopods (Leptodus) from Texas, had been blocked by Grant's senior colleague: "Apparently, Cooper has such antipathy for the likes of you and me that when he found out that this fellow was working with me and using your approaches and ideas, he wouldn't even let him look at most of the specimens" (Gould to Rudwick, 28 November 1970).

After the New Orleans symposium was published (Macurda, 1968), Gould told me, "I'm doing a review on the science of form (whatever that is) for Earth-Sciences Reviews and am quoting MJSR[udwick] all over the place"; alluding to the paradigm method, he added, "It's amazing how many paleontologists are ashamed of their mechanistic thinking in functional morphology" (Gould to Rudwick, 2 April 1969). This major article on "Evolutionary paleontology and the science of form" (Gould, 1970) opened with the claim that "A science of form is now being forged within evolutionary theory"; citing my original formulation of the paradigm method (Rudwick, 1961), he stated that "The approach of a structure to its paradigm provides the elusive criterion of relative efficiency that any science of adaptation requires." He linked my work with Raup's theoretical morphology, noting that "Actual forms fill only a part of the total spectrum; their basic adaptation may be grasped when we realize why unoccupied areas are not utilized." $\mathrm{He}$ argued that the combination of Raup's ideas and mine, quantitative and functional, introduced "a new methodology" that he called "quantifunctional"; he pointed out that it suggested that in life's history "parallelism and convergence are dominant phenomena, not mere taxonomic nuisances" (Gould, 1970, pp. 77-78). Citing my functional analysis of zigzag valve edges in fossil brachiopods (Rudwick, 1964a), he argued that these phenomena involved "the attainment of mechanical optima or Rudwickian paradigms" - by this time the quite different meaning of "Kuhnian paradigms" was widely known among scientists simply because "they provide a selective advantage that leads, over and over again, to their attainment in competition" (Gould, 1970, p. 110). This made explicit what I had taken for granted: that the driving force behind every approximation to a structure of paradigmatic form was nothing other than ordinary Darwinian natural selection. 
Gould's paper illustrated this nascent "science of form" by reviewing a wide variety of recent research by many different paleontologists, setting it in a historical context that linked it back through D'Arcy Thompson to nineteenth-century functional morphology. Referring to the pattern of large-scale evolution that he claimed was now discernible in the fossil record, Gould concluded that "We now have the outline of a history [of life]: the weeding out of unsuccessful designs and multiple evolution of mechanical optima"; and that "major groups often have a history that can be described on the basis of a few functional themes" (Gould, 1970, p. 111). In a later article on "D'Arcy Thompson and the science of form" (Gould, 1971a), aimed at the quite different readership of New Literary History, he emphasized again the crucial importance in this context of thinking in "mechanistic" terms. Like Pantin (1951) long before, though perhaps without knowing of that influential essay, Gould argued that biologists should not be embarrassed to use the language of "organic design," and should not be inhibited by the outworn historical legacy of Paley's deistic "argument from design."

\section{Seilacher's "Constructional Morphology"}

The combination of Raup's computer-aided theoretical morphology with my own (and many others') functional morphology, as proposed in Gould's "quantifunctional" approach, was taken further as a result of Raup's links with the paleontologists at Tübingen. This historic center of research on "Paläobiologie" was now headed by Adolf Seilacher (1925-2014), who had succeeded his mentor Schindewolf in 1964 (on the background history of this German morphological tradition, see for example Laubichler and Niklas, 2009). Seilacher's innovative "Palichnologie" had earlier analysed "trace fossils" such as tracks and burrows in terms of animal behavior (Seilacher, 1953a, b). Raup's visit to Tübingen resulted in a brief but important joint note in Science, in which they interpreted certain trace fossils in terms of systematic "foraging behavior" by the unpreserved organisms; and this was now supported by a "computer simulation" that convincingly replicated the observed forms of the fossil tracks (Raup and Seilacher, 1969). This represented an important further use of computers in the service of paleobiology.

Seilacher thanked Raup for having, in their seminar at Tübingen, "taught us how fossils can be understood in terms of theoretical morphology." But in fact this significant acknowledgement was appended to 
a separate paper, published in Palaeontology, that was primarily concerned with functional morphology (Seilacher, 1968, p. 281). Functional morphology, Seilacher stated, was "a most important tool in the interpretation of specialised forms that deviate ecologically from their relatives"; as examples he cited my bizarre richthofeniid brachiopods and his colleague Vogel's almost equally bizarre brachiopod Pygope (Rudwick, 1961; Vogel, 1966). His own case was that of a fossil stalked crinoid (Seirocrinus) of large size and unusual morphology, well preserved in distinctive black shales that geologists attributed to originally euxinic bottom conditions (in which crinoids could not have survived). Seilacher suggested an elegant solution to this paradox: these crinoids, unlike most others, had not grown upwards, plant-like, from attachments on the sea-floor, but instead had dangled downwards from attachments to unpreserved materials such as driftwood floating at the surface. This accounted functionally - on predictable mechanistic principles of organic design - for the crinoids' aberrant morphological features.

Seilacher's combination of theoretical and functional approaches to fossil morphology was set out in a brief but important note in Lethaia, a recently-founded multilingual journal (edited at Uppsala in Sweden) "for palaeontology and stratigraphy," which had already shown itself to be receptive to newer kinds of research. Seilacher's note (1970) was titled modestly an "Arbeitskonzept"or working draft; it was intended to introduce further papers by himself and his colleagues, on what he defined as "Konstruktions-Morphologie." Seilacher adopted the visual idiom of the triangular or "ternary" phase-diagrams used by physical chemists, mineralogists and other scientists: he depicted "constructional morphology" as the product of three "aspects" or "factors" at the corners of a triangle: "historical-phylogenetic," "ecological-adaptive" and "fabricational" [bautechnischer] (Figure 6).

Of these, the first two need no special explanation. In principle, it is obvious that the morphology of an organism can be described in terms of its phylogenetic legacy, developed as an anatomical ground-plan [Bauplan] in the course of its evolutionary history: to interpret organisms in this way had been the goal of much paleontological research ever since Darwin. Equally clearly, the pre-Darwinian tradition of functional morphology had now been revived in an evolutionary context: Seilacher referred to my methodological paper (Rudwick, 1964b) as having given a new uplift [Aufschwung] to Othenio Abel's "Paläobiologie" (Abel, 1912), exemplifying this "ecological-adaptive" factor or "FunktionsMorphologie." The third corner of Seilacher's triangle was perhaps more 


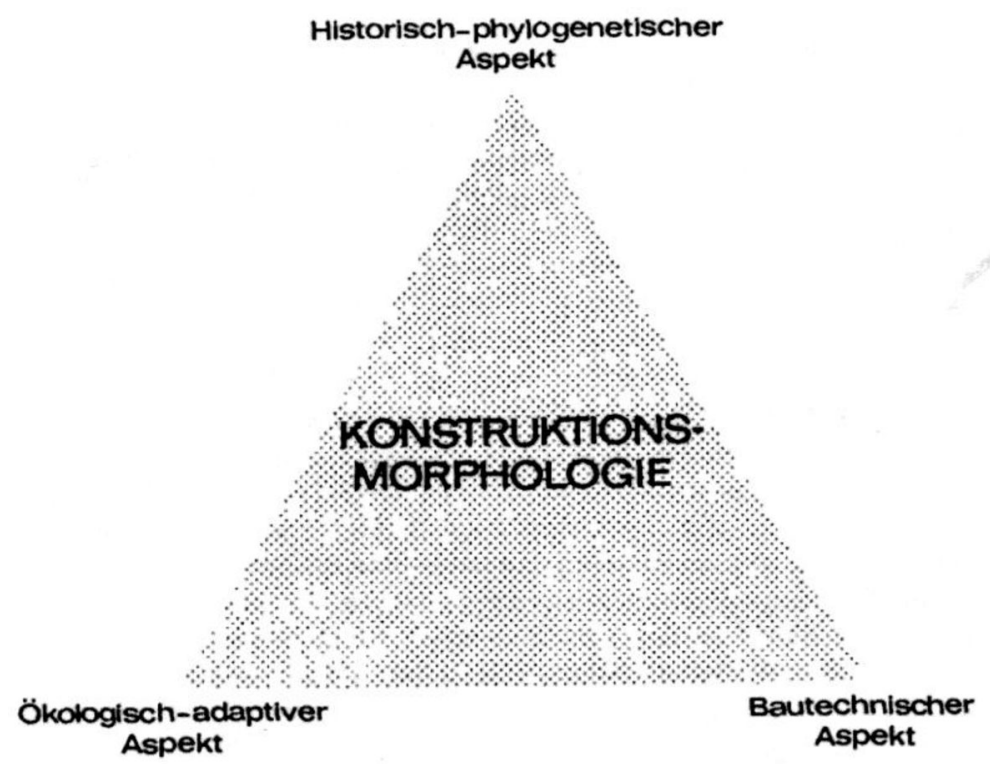

Figure 6. Seilacher's tripartite or ternary analysis of morphology. "In constructional morphology the phylogenetic, adaptive and fabricational aspects of a given structure are set against [gegenübergestellt] one another, and each structure appears as a compromise between ground-plan [Bauplan], paradigm and fabricational program" (Seilacher, 1970, Figure 1; by permission of John Wiley and Sons [my translation]). "The predominance of any of these criteria dictates from case to case the position within the triangle of the interpreted structure" (this sentence was added to the English version of the caption; the text of the paper was in German)

puzzling to those unfamiliar with his intellectual heritage, namely the kind of evolutionary theorizing advocated earlier by Schindewolf and other German-speaking paleontologists. Seilacher himself translated "bautechnisch" as "architectural," but later (and better) as "fabricational" (Seilacher, 1979, p. 191). It drew attention to the basic constraints on organic form that reflect what is physically "possible in this universe of ours," as Pantin had put it, independently of either the Bauplan or phylogenetic legacy of the organism, or its functional requirements or adaptations. In Raup's "theoretical morphology," for example, these fundamental constraints were expressed in the matrices of all possible spiral shell forms, which his computer programs had so elegantly generated and displayed. They were likewise expressed in my emphasis on the limited alternative classes of design (grilles, meshes, slits) possible for protective devices in the specific case of brachiopods: analogous, say, to the possible classes of designs for bridges, which Thompson and Pantin had both invoked. More generally, they were 
expressed - although much too briefly and baldly - in the crucial qualifying phrase in my original definition of a paradigm as "the structure that can fulfill the function with maximal efficiency under the limitations imposed by the nature of the materials" (Rudwick, 1961, p. 450; emphasis added).

By adopting the format of a ternary phase-diagram and calling any real structure a "compromise" between his three "aspects" or "factors," Seilacher treated them as variables, the relative strengths of which might be estimated in any given case (though he did not suggest that this could be precisely quantified). For example he located certain fossil cephalopod shells - the Paleozoic ammonoids analyzed in the paper (Kullmann and Scheuch, 1970) printed immediately after his prefatory note - as being near the bautechnischer corner. This implied that their morphology was governed predominantly by fabricational constraints, much more than by their functional role or their evolutionary origin. This was the sense in which Seilacher's tripartite scheme was generally interpreted (see Reif, 1975; Briggs, 2005a, b). However, had he emphasized "aspects" rather than "factors" (he used the terms interchangeably), his analysis might have allowed for the possibility that any morphological feature could be fully described, at least in principle, in any of three complementary ways - in terms of phylogeny, functions or fabricational elements - without these being regarded as alternatives.

Seilacher invited Raup and Gould to a meeting that he organized in Tübingen in 1971 to discuss his idea of Konstruktions-Morphologie. In a brief published report to his compatriots, Gould (1971b) noted the scientific contrasts between the German- and English-speaking paleontologists present, and the great attention that the former had long given to basic questions of organic form. This he himself now endorsed. He also referred to "the honored method of studying functional morphology via odd adaptations," alluding to his host's recent work on crinoids of odd form, but also to my own and Cowen's odd Permian brachiopods. His use of the word "odd" might have been taken to imply that he was relegating such interpretations to the theoretical margins; but on the contrary he intended it to highlight the special value of "odd adaptations" as keys to the interpretation of morphologies of less aberrant form. This became clear in his paper on "Muscular mechanics and the ontogeny of swimming in scallops" (Gould, 1971c), published at just this time. He claimed that "some of our best works on the functional morphology of fossil invertebrates" dealt with unusual forms, simply because "these adaptations are experiments that test the limits of form": such fossils furnish "a criterion for judging the relative efficiency 
of structures by the mechanical analysis of organic design as Rudwick proposes in his notion of the paradigm." He concluded that "we need a palaeontology of the present to develop our functional morphology into a science of form" (Gould, 1971c, p. 61; emphasis added). Swimming bivalves such as scallops, which the paper analyzed in detail in mechanical terms, were examples of just such instructive oddities: they were living experiments that could be used to enrich the "paleontology of the past.'"

Seilacher's programmatic unification of all aspects of morphology had already been furthered on a personal level when Raup, now at Rochester (N. Y.), began to collaborate with Stanley. Greatly enlarging his earlier paper on the functional evolution of bivalve molluscs, Stanley published his research in full as a substantial monograph on the "Relation of shell form to life habits of the Bivalvia" (Stanley, 1970). He noted that most previous studies of functional morphology had dealt with fossil forms, and that "Many have been consciously or unconsciously patterned after the philosophic scheme recommended by Rudwick (1964b)." However, while accepting "the fundamental role of mechanical analogy in all functional-morphologic interpretation," as in the paradigm method, Stanley noted as before that his own work could be almost wholly keyed to living forms, because many of the major kinds of bivalve are still alive in the present world and their ways of life can be observed directly. He also emphasized what had been implicit in other such studies (including mine), namely that morphological structures often clearly represent compromises between the conflicting demands of more than one function: as an example he referred to the external spines on the shells of certain living bivalves, which help to stabilize the mollusc embedded infaunally in a soft substrate, but at the same time unavoidably hamper its ability to move its position should the need arise.

The following year Raup and Stanley published their subsequently influential joint textbook Principles of Paleontology, which conspicuously promoted and consolidated the place of paleobiological approaches to the study of fossils (they had initially considered using the neologism Geobiology in the title, which illustrates the continuing liminality of "paleobiology"). Specifically, a substantial chapter on "Adaptation and Functional Morphology" summarized much recent research and made it attractively accessible (Raup and Stanley, 1971, pp. 155-193). Among their examples were Stanley's own molluscs, Clarkson's trilobite eyes, and one of my peculiar brachiopods, as well as dinosaur jaws and ammonite shells; in describing the last of these, they 
noted that "We can formulate a paradigm for each hypothesis," using analogies drawn from the world of engineering (pp. 172-181).

\section{Functional Morphology and Evolutionary Theory}

That the paradigm method had now reached some level of familiarity among paleontologists, and perhaps even of acceptance, is also suggested by Raup's contribution to an equally influential volume, published the following year. In an essay on "Approaches to morphological analysis" (Raup, 1972) he noted that much recent paleobiological research, following "a series of brilliant morphological analyses by Rudwick," had focussed on the functional interpretation of "specific morphological structures," so that the "functional factor" in Seilacher's (1970) conceptual analysis "might be called the Rudwick corner of the triangle." Raup argued that any apparent discordance between Seilacher's analysis and my paradigm method was only a matter of emphasis. He accepted that my qualification about the "nature of the materials" available for forming functional structures showed that I had been well aware, not only of the intrinsic "fabricational" limitations on the optimization of adaptations, but also of the contingent phylogenetic limitations. Yet he felt that "these factors have been relegated to such a minor status that many followers of Rudwick have tended to neglect them (particularly the phylogenetic factor)" (Raup, 1972, pp. 29-35). In effect, he was worried that the paradigm method, with its "mechanistic" focus on functions and adaptations, might have become too successful and persuasive, to the detriment of the essential evolutionary perspective!

Raup's essay was published in Models in Paleobiology (Schopf, 1972a). This volume was derived from a symposium held during a meeting of the Geological Society of America in Washington D.C. in 1971, paralleling the earlier one in New Orleans (this time the sole speaker from outside America was Hallam). It was organized, and the book was later edited, by Thomas Schopf (1939-1984) [not to be confused with his younger brother William Schopf (1941-), also a prominent paleontologist]. Thomas Schopf first approached James Valentine (1926-) of Davis (California), a distinguished paleontologist who supported his plan for such a meeting and urged him specifically to "emphasize the great power of models to explain or at least rationalize the fossil record." Schopf agreed on this theme, noting that appropriate possibilities for modeling "occur in problems of growth, morphology, 
ecosystems, community structure, speciation, and biogeography"; as contributors he suggested (among others) Gould for growth, Raup for morphology, Hallam for populations, and Valentine himself for ecosystems. His appeal to them all emphasized his aspiration that the meeting and the subsequent book should transcend the conventional taxonomic tradition and instead "encourage the analytical "problem oriented' approach to paleontology" (Sepkoski, 2012, pp. 140-141).

Schopf's editorial introduction to Models in Paleobiology reiterated this belief that an "analytical approach" was best able to lead to a "reinvigoration of paleontology." His own contribution set out his broad understanding of models and modeling (though misleadingly he treated Kuhn's kind of "paradigm" and mine as variants of the same idea: Schopf, 1972b, p. 11). The essays that followed displayed their authors' diverse ideas about what an "analytical" approach might entail. What is striking about the collection as a whole is the rather small part played by what had hitherto been treated, notably in Europe, as some of the major themes of "paleobiology." Raup's essay was the only one to deal systematically with morphology, and the diverse "ways of life" of the organisms of the deep past received only passing attention elsewhere. Conversely, many of these other essays were focused on the analysis of the fossil record in quantitative terms and with its evolutionary interpretation. In effect, the volume illustrated an increasingly clear differentiation between two complementary conceptions of "paleobiology." Both were potentially quantitative and both could exploit the new capacities of computers; but they were focused either on the evolution of the "ways of life" of specific extinct organisms, or on the analysis of the fossil record of specific taxonomic groups of organisms and the evolution of life as a whole. To put it somewhat crudely, the first was rooted in the European tradition of "Paläobiologie," the second in the American tradition of "paleobiology" exemplified by the work of Simpson and Newell in the postwar years.

The latter tradition was most notably represented in the Models volume by the essay that subsequently attracted by far the most attention. Schopf had asked Gould to write about "models of speciation." This he eventually accepted; he would have preferred to tackle the themes of morphology or phylogeny, but they had already been allocated to others (Sepkoski, 2012, pp. 142-149). Gould enlisted Niles Eldredge (1943-) of Columbia as his co-author: his own work on evolutionary trends in Pleistocene snails in Bermuda was then reinforced by Eldredge's recently completed study of trends in the trilobite Phacops in the Devonian formations of New York state (Eldredge, 1971, 1972). 
They used their respective fossils to argue for a radically unconventional interpretation of trans-specific evolutionary change (Eldredge and Gould, 1972). What they called "punctuated equilibrium" was contrasted with "phyletic gradualism": a model of very long periods of stability of structure, interrupted only occasionally by relatively rapid morphological changes, was contrasted with a model of slow but steady change over the same periods of geological time. They claimed that their fossil evidence supported the former model, whereas the mainstream of paleontological opinion - ever since Darwin - had considered the latter to be the usual form of evolutionary change (its steady continuity being obscured by the presumptive imperfection of the fossil record). The idea of punctuated equilibrium immediately provoked vigorous controversy, not only among paleontologists but more broadly among evolutionary biologists (Sepkoski, 2012, pp. 149-184).

In the present context, however, what is most striking about this subsequently famous - or notorious - paper is that these alternative interpretations of the mode of small-scale evolution were discussed wholly in terms of biometrics and statistics, not in those of functions or adaptations. For example, the specific morphological feature that was highlighted in the analysis of the evolution of Eldredge's trilobites was the variable number of vertical "files" of lenses in the animals' compound eyes. On this point, the first of Clarkson's papers (1966a) on trilobite eyes was cited, but only for the morphology of the eyes, not for his functional interpretation of trilobite vision: the possible adaptive significance of the evolutionary changes in the number and arrangement of the lenses was left unexamined. In effect, functional morphology, and its possible value for the interpretation of evolutionary change, was sidelined, in favor of more readily quantifiable parameters.

This relative neglect of questions of function and adaptation had in fact been a feature of paleontological research on speciation, ever since the British geologist Arthur Trueman (1894-1956) first used biometric and statistical methods to study the changing forms of the fossil oyster Gryphaea (Trueman, 1922). Trueman's primary goal was conventionally stratigraphical, but he had also related his findings to the broader biological debates of his time, about the roles of orthogenesis, natural selection and other possible factors in evolutionary change. In the postwar decades, the rich fossil record of Gryphaea in the early Jurassic (Liassic) formations in Britain - with their well-exposed sequences of strata and their exceptionally precise relative dating (based on stratigraphical "zones" characterized by a geologically rapid succession of distinctive ammonite species) - had become a locus classicus for debates 
about the nature of evolutionary changes at the trans-specific level. These studies (e.g., Joysey, 1959; Philip, 1962; Hallam, 1968) used the best statistical methods, and later harnessed the novel capacities of early computers, to analyze the morphological trends that could be detected when Gryphaea shells were traced through geological time. Their authors were aware that such trends might have had functional and ecological implications (e.g., keeping the shells in stable positions on soft substrates, and their valve edges clear of the mud). But the main focus of this research was on the biometrics of the shells, not on the possible functional or adaptive significance of the morphological changes themselves. This was in notable contrast, for example, to Nichols's analysis of comparable micro-evolution in the Cretaceous sea-urchin Micraster, which he had interpreted in detail in terms of changing adaptations (Nichols, 1959a, b). In effect, the fossil oyster shells, like the trilobite eyes, were treated - albeit with impressive quantitative methods - as objects that had evidently changed in form over geological time, whether slowly or rapidly, but which might just as well have been mineral objects of inorganic origin.

This quantitative approach to the use of fossils for evolutionary theorizing soon began to be taken much further. In 1972 Raup and Gould were joined by Schopf and Daniel Simberloff (1942-) - all still under forty - in informal meetings at the Marine Biological Laboratory [MBL] at Wood's Hole (Massachusetts), to discuss the potential of computer-aided statistical methods to interpret the larger features of the fossil record. For Raup, intellectually the leader of this "MBL" quartet, this new project involved transferring his attention and his methods from the theoretical morphology of the individual organism to the statistical analysis of fossil taxa, traced through all periods of Phanerozoic time (i.e., from Cambrian to the present). His computerized simulation of physically possible shapes of shells was now paralleled by an equally innovative "stochastic simulation" of large-scale patterns of phylogeny. Raup's intellectual move epitomized the dichotomy of traditions within "paleobiology": his focus of attention shifted from the analysis of the morphology of fossil organisms to the meaning of their overall fossil record. Both approaches were quantitative in outlook and both made good use of the growing potential of computers, but their objectives were quite distinct.

Raup and his collaborators launched a program for research on what they termed "nomothetic paleontology" (Raup et al., 1973; Raup and Gould, 1974). In contrast to the traditional "idiographic" approach, which was blamed for "some of [paleontology's] current sterility," 
nomothetic paleontology was to search for "general laws" rather than clarifying individual cases. In effect, the scientists whose practice was to be emulated were physicists, not naturalists. Using Raup's computer programs, this nomothetic approach was illustrated with some impressive simulations of the conventional visual depictions of the phylogenetic histories of fossil taxa, with different patterns of origins, diversities, and extinctions. The group claimed that such simulations showed how much of these characteristic patterns of evolution were explicable as the product of stochastic systems, almost irrespective of the evolutionary mechanisms involved (Figure 7).

All this work was based in the first instance on the data assembled in Harland's earlier Fossil Record (1967), which the group acknowledged to be "by far, the best we have," although "inevitably inadequate in some respects" (Raup et al., 1973, p. 536). But their additional use of the vast database of taxonomic information provided by the recently completed Treatise on Invertebrate Paleontology (Moore, 1955-1971) highlighted their marginalizing of questions of function or adaptation, for it reduced morphology to the statistics of the units that these sources defined as species, genera and higher taxa. The stylistic uniformity of the Treatise masked the uncertainties arising from the notorious diversity of practice among taxonomists - who were recognized colloquially as being by inclination either "lumpers" or "splitters" - in what they defined as relevant taxa. This was a problem that had been all too apparent to the many paleontologists (I was one of them) who had earlier collaborated in compiling The Fossil Record. It lent a deceptive air of objectivity to what, after Schopf's untimely death, Gould recalled as his "vision of "species as particles' (his phrase)" (Gould, 1984, p. 280) and his frequent metaphorical reference to the "gas laws" of speciation. This quantitative treatment of fossil taxa as natural entities analogous to atoms or molecules in physical systems had the probably unintended consequence of diverting attention ever further away from whatever adaptive differences might have underlain the evolution of their varied morphologies.

Raup's group conceded that stochastic systems did not tell the whole story. Their program also focused attention on the possible reality of mass extinction events - not least "the Permian extinction, paleontology's outstanding dilemma" (Raup and Gould, 1974, p. 539) - the fossil traces of which could not be explained solely in terms of stochastic processes. And the functional dimension was still to have a place, albeit a marginal one, in the new style of nomothetic paleontology: "We shall have to look elsewhere - particularly to functional morphology - for 


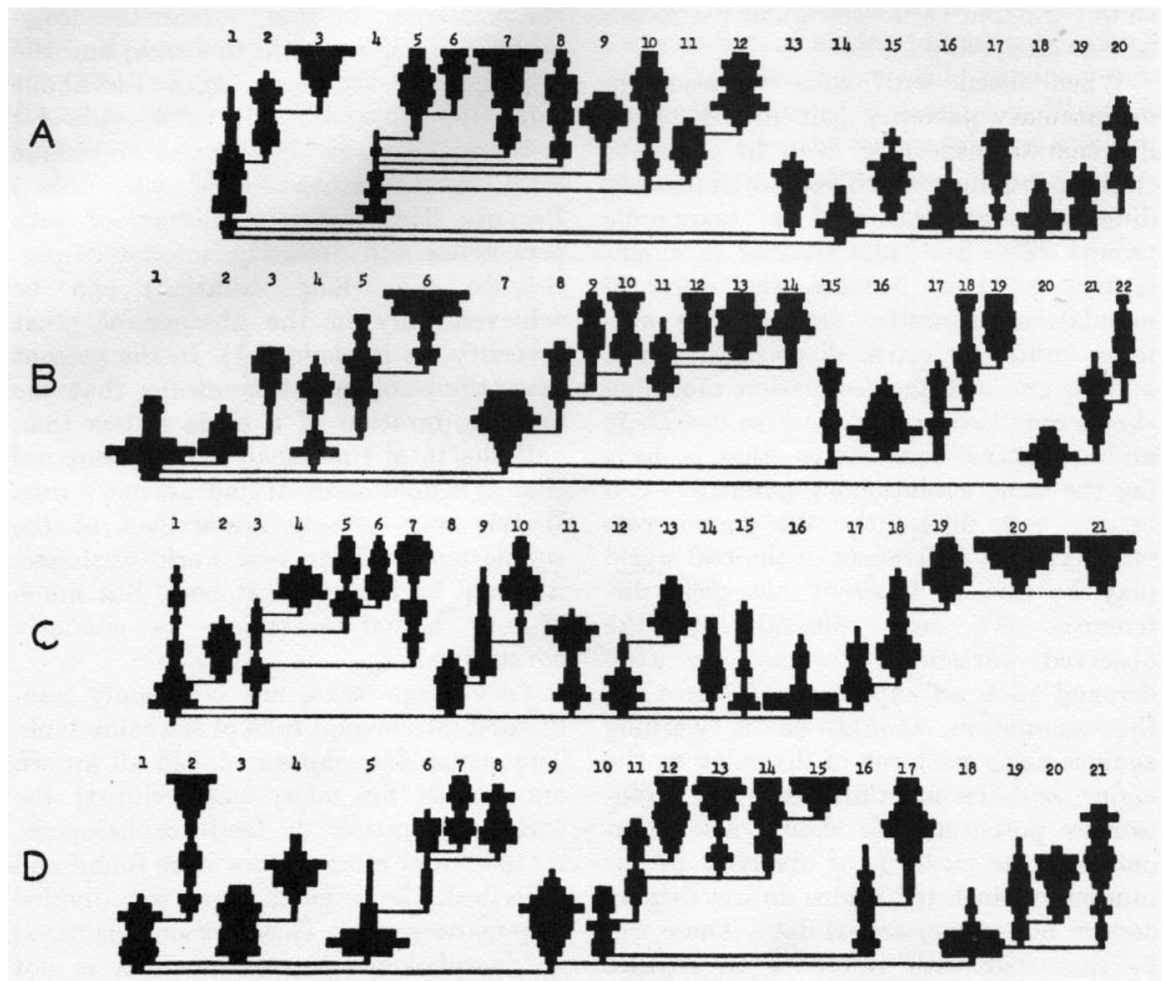

Figure 7. Computer simulations of the evolutionary history of fossil taxa: "Diversity variation and phylogeny of the clades produced by four computer runs, [using] the same input constants but different random number sequences" (Raup et al., 1973, Figure 5; by permission of University of Chicago Press). Hypothetical time flows upwards, as in the similar graphical displays of inferred phylogenies already familiar to paleontologists (based on the diversity of the taxa found as fossils in successive stratigraphical formations). The taxonomic units - species, genera or families - represented by these "spindles" were wholly abstracted from whatever diverse adaptations or ways of life the organisms might have had; this kind of statistical analysis had no necessary link to their functional morphology

evidence of uni-directional selection and adaptive evolutionary trends," they conceded; "adaptation is better demonstrated by studies of the mechanics of form in relation to environment than by evidences of directional change through time." Raup and Gould even described their joint paper as being, among other things, "a plea for the devotion of more attention to the neglected but growing field of functional morphology in paleontology" (Raup and Gould, 1974, p. 321; emphasis added) 
Nonetheless, and despite that plea, the turn towards the statistical analysis of the fossil record was at least partly responsible for the relative eclipse of research areas such as functional morphology and, within it, of the paradigm approach. In subsequent years, quantitative research on the fossil record became both prominent and highly successful in its influence on evolutionary biology. Indeed its success was such that, particularly in North America, it became almost synonymous with the concept of "paleobiology" itself (see Sepkoski, 2005, 2012; and essays in Sepkoski and Ruse, 2009). Yet, as so often in the history of the sciences, this major shift in the focus of research had its down side. This was surely unintended. But in practice what was subjected to statistical analysis were taxonomic units - whether species, genera or families which, like Gryphaea shells, might just as well have been inorganic entities, not organisms or groups of organisms that in the course of evolution had developed many diverse ways of making their living in the world. (It is at least arguable that in practice the more recent vogue for cladistics shares this characteristic.)

Meanwhile, at least in the short run, more qualitative kinds of paleobiology were not neglected. For example, Cowen and his senior Californian colleague Valentine collaborated in writing a substantial essay on "An adaptive model of the origin and history of the brachiopods" (Cowen and Valentine, unpublished, [1973]). As the title suggested, this was an ambitious interpretation of the entire evolutionary history of the phylum in terms of adaptation, and therefore with close attention to functional morphology. My own earlier attempt at such a synthesis (Rudwick, 1970) had been arranged around the various functional systems of brachiopod life (e.g., "senses and protection," "lophophore and feeding"), with just a brief synthesis of the animals' overall evolutionary history. Cowen and Valentine integrated evolution and adaptation much more closely. They offered a coherent functional and ecological interpretation of the whole history of the phylum. This followed the history of brachiopods all the way from their likely origin (as small "lophophorate" animals, probably very early in Cambrian time), through their greatest taxonomic and adaptive diversity in the middle of the Paleozoic era and their dramatic reduction at its end, to their modest but persistent survival since that time. This synthesis also related the adaptive history of brachiopods to the evolution of other organisms over the same periods of time (e.g., bivalve molluscs, as explored earlier by Stanley). The paper was sent to be assessed by Cooper, who was rightly regarded as the world's leading authority on fossil brachiopods. Regrettably, as Cowen recalls, Cooper "wrote a brief and 
dismissive review saying (I forget the precise wording) that what was old in the manuscript was already known, and that what was new was wrong" (Cowen to Rudwick, 12 July 2016). Its authors, discouraged by that damning dismissal and understandably reluctant to rewrite their paper, never published it.

In a small way, however, it contributed to a work of much wider scope that was then in press. Valentine's Evolutionary Paleoecology of the Marine Biosphere (Valentine, 1973) was highly influential in that it integrated paleoecology decisively into the evolutionary interpretation of the fossil record. It included a substantial chapter on "The mode of life and functional range of fossil organisms" (pp. 147-225), in which, among many other examples from different phyla, Valentine summarized Cowen's and my work on brachiopods in positive terms. And it set all this functional morphology in a wide context, which in the early 1970s - with crustal mobilism at last gaining rapid acceptance among geologists and geophysicists - included issues of global paleogeography and paleoecology as possibly major causal factors in the history of life. Valentine made no explicit reference to the paradigm method as a way of reconstructing "the mode of life and functional range of fossil organisms." But perhaps the method had just come to be internalized among those paleontologists who were aware of it; or perhaps at least the habit of thinking about observable structures in relation to optimal organic designs had just come to be treated as routine by those who were trying to interpret the morphology of their fossils in terms of functions and adaptations.

This suggestion is supported by the example of Clarkson, whose early work on trilobite vision (Clarkson, 1966a, b) had, as already mentioned, referred positively to the paradigm method yet without deploying it explicitly. In the following years Clarkson had published further impressive papers on the eyes of trilobites. They culminated in one that he wrote in collaboration with a physicist and published in Nature (Clarkson and Levi-Setti, 1975). This showed how the microanatomy of individual lenses in some exceptionally well-preserved "schizochroal" trilobite eyes would have corrected for spherical aberration and produced accurate images in what was in effect "an aggregate of individual eyes," rather than the visual mosaic produced by the compound eyes of other trilobites (with "holochroal" eyes) and other arthropods. These fossil eyes were said to display "the optics of Des Cartes and Huygens" in an astonishingly precise example of organic design. Cowen and his students took this even further, showing how the spatial arrangement of the lenses could have given the trilobites 
stereoscopic vision, and how neural connections analogous to those known in living arthropods could then have given them accurate perception of the movements of other benthonic animals around them (Cowen and Kelley, 1976; Stockton and Cowen, 1976). The inspiration for the first of these papers had come when Cowen's student noticed an analogy between the distinctive arrangement of the lenses and the strategy used by aircraft surveying an area to produce a three-dimensional image of its topography (Cowen to Rudwick, 26 October 2016). This was another example of the heuristic power of what some paleontologists were dismissing as an unduly "mechanistic" attitude to morphology. And in this context the concept of paradigms was not wholly forgotten: in a new edition of their Principles of Paleontology, Raup and Stanley called functional morphology "an extremely important area of research" and noted that "As an application of Rudwick's paradigm [method] to problems of functional morphology, the example provided by the trilobite lens is unsurpassed!' (Raup and Stanley, 1978, p. 182).

\section{The Paradigm Method Under Attack}

At this point the present narrative needs to backtrack a few years, to describe how the paradigm method had encountered substantial criticism on its home territory. This episode probably contributed, though with questionable justification, to the later decline or eclipse of the method. My interpretation of the unusual morphology of richthofeniids in terms of an equally unusual feeding mechanism (Rudwick, 1961) had been presented, deliberately, not only as an initial explanation of the paradigm method, but also as a test case for its validity and value. It had been widely cited as an example of how the functional morphology of invertebrate fossils could be investigated, particularly where relevant analogies with living organisms were lacking or problematic. Any wellinformed criticism of my suggestion of an unusual "flapping" mechanism in these morphologically unusual brachiopods therefore carried implications extending far beyond this particular case. When such criticism came, it came not surprisingly from Grant, who in his referee's report on my New Orleans paper had already been highly critical of the paradigm idea, and who at the same time was of course familiar with the relevant Permian brachiopods. In 1970 Grant submitted a lengthy paper to the Journal of Paleontology, most of which was a conventional taxonomic description of some new Permian brachiopods from the Greek 
island of Idhra. However, Grant introduced this paper as also "affording opportunity for a critique of Rudwick's 'paradigmatic method' of functional analysis" (Grant, 1972, p. 213). It was published at about the same time as Raup's more positive essay in the Models volume.

Grant's new brachiopods from Greece were almost as well preserved (by silicification) as the prolific brachiopod faunas that he and Cooper were describing from Texas. They were tiny cup-shaped productides (notably his new genus Falafer), in which the lid-like dorsal valve bore on its inner side a series of shelly ridges that had obviously supported one of the forms of lophophore ("ptycholophe") that were well known in some very small living brachiopods. Grant reconstructed the likely appearance of these brachiopods in life, the likely arrangement of the filaments on the lophophore, and the likely water currents that its cilia could have generated for its suspension-feeding system. All this was based on accounts of living brachiopods, mine among them, and was a plausible functional interpretation. However, Grant was seemingly unaware of the long-standing biological debates on growth and form as revived for example by Gould - and specifically on allometric growth and the significance of dimensional effects. Without taking absolute size into account, Grant extrapolated from his tiny new brachiopods to all productide brachiopods of every age and size: he attributed the same form of lophophore to them all (they include some of the largest brachiopods known; in most of them no trace of the lophophore is preserved, and its form is altogether conjectural).

For the richthofeniids in particular, Grant claimed that there was no need to postulate any unusual feeding mechanism, despite their very peculiar morphology, and that they had all operated a normal suspension-feeding system powered by cilia. On this interpretation, however, his proposed reconstruction of the water currents in and out of a richthofeniid was difficult to reconcile with the preserved morphology; it also showed little understanding of the basic principles of functional efficiency that clearly govern the current systems of all living suspension-feeders of whatever phylum. Even more seriously, Grant left unexplained all the strange morphological features - such as the delicate "trap-door" dorsal valve and its elegant hinge mechanism, the thickets of internal spines of Prorichthofenia permiana, and the delicate mesh of P. uddeni - which the suggestion of rapid "flapping" movements had interpreted in terms of an unusual method of food collection. Minimizing the unusual features of richthofeniids and lyttoniids, Grant argued that both groups had been entirely normal in their methods of 
feeding; invoking Occam's razor, he rejected any suggestion that they had been significantly aberrant (Figure 8).

Grant used his scepticism about any "flapping" mechanism for richthofeniids as the basis for rejecting comprehensively what he termed the "Rudwickian" or "paradigmatic method" for the functional interpretation of fossils of any kind. As he put it scornfully, the method merely "lends scientific tone to an hypothesis that has a very low level of probability." While noting that it had "received wide acclaim" and even been taken "to mark a watershed in the conceptual methodology of invertebrate paleontology," Grant dismissed it on the grounds that in the case of richthofeniids and lyttoniids "it has produced erroneous

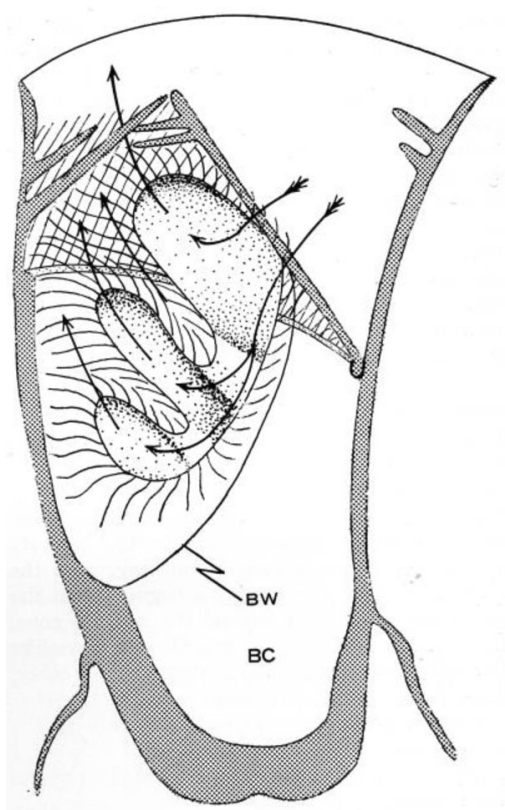

Figure 8. Grant's reconstruction of a "generalized richthofeniid" brachiopod, with the trapdoor-like dorsal valve in what he argued was its normal small angle of opening (Grant, 1972, Text-fig. 8; by permission of the Society for Sedimentary Geology). The lophophore below the dorsal valve was reconstructed as the simple "ptycholophe" form, although among living brachiopods this was known to be restricted, for clearly dimensional reasons, to very small species. And the inferred inhalant water currents (tailed arrows) were shown entering past the sides of the trapdoor, although in the fossil specimens there is often no physical gape at all at that point, whatever the angle of opening; and the exhalant currents (arrows without tails) were shown having to traverse the obstruction of a dense thicket of spines. Given the morphology preserved in fossil richthofeniids, the ciliary suspension-feeding mechanism proposed by Grant would therefore have been highly inefficient or even unworkable 
conclusions." Although he conceded that Clarkson's studies of trilobite vision showed that on occasion it could "produce excellent results," he downgraded it from a "method" to a mere "point of view" or "approach" (Grant, 1972, pp. 235-236).

In a paper submitted at almost the same time as Grant's, but to another journal, Cowen (1970) suggested an important extension to our earlier interpretation of both richthofeniids and lyttoniids. As already noted, these bizarre brachiopods had ventral valves with spreads of shelly material extending far beyond the deeply recessed dorsal valve. These shelly tracts must have been secreted by, and covered in, equally extensive spreads of exposed mantle tissue. Cowen argued that they were closely similar to the spreads of permanently exposed tissue around the valve edges of living "giant clams" (Tridacna), which are prominent on many tropical coral reefs. In these molluscs this tissue incorporates symbiotic zooxanthellae that provide, by photosynthesis, an important supplementary source of energy. If richthofeniids and lyttoniids had incorporated similar symbionts, it could explain further features of their strange morphologies (in addition to those explained by their putative feeding mechanisms). No direct evidence for this kind of symbiosis had of course been preserved in the fossils; but the inference could be supported indirectly, if the ordinary clues of paleoecology indicated that these aberrant brachiopods, like the living giant clams, had been confined to clear shallow tropical waters such as those of reef environments. Cowen argued that the known geographical range and paleoecological context of these Permian faunas were indeed compatible with this inference.

While Grant's critique of the paradigm method was still in press, he himself unwittingly added weight to Cowen's idea. He published a straightforward paleoecological interpretation of the extensive "reefs" ("bioherms") in the Permian rocks of the Glass Mountains (Grant, 1971). He showed that they had been built, almost certainly in tropical environments similar to modern coral reefs, by many unrelated organisms, among which the aberrant brachiopods were certainly prominent.

I had in effect withdrawn from this debate, mainly under the practical pressures of my new teaching duties in what was for me a radically new academic field. But while Cowen was preparing a response to Grant we received unanticipated support from Paul, who, as mentioned earlier, was working on the functional morphology of the extinct cystoid echinoderms. Paul told us he was using our interpretations of brachiopods in a teaching course on "controversial topics in palaeontology," and he suggested that he himself should write a paper in response 
to Grant's critique. However, he warned us that "whereas I reject Grant's general criticisms of the paradigm method I find his interpretation of Prorichthofenia and the lyttoniids very persuasive" (Paul to Rudwick, 11 July, 23 November 1973). After some discussion, Paul and Cowen agreed to write complementary papers for Lethaia: Paul on the method in general, Cowen on the specific case of the bizarre brachiopods.

At the start of his paper, Paul stated that "The most important feature of the paradigm method is that it allows functional hypotheses to be tested [and] therefore offers the possibility of removing functional interpretations from the realm of speculation" (Paul, 1975, p. 15; emphasis original). This was wholly in accord with my own conception of the method. Unfortunately, however, Paul summarized paradigms as structures "which are $100 \%$ efficient in performing proposed functions." This laid his argument open to misinterpretation, in that it could obscure the crucial distinction between the ideal and the paradigmatic. This in turn could divert attention from the intrinsic limitations of the latter, as emphasized for example by Seilacher: namely, that morphologies are bound to have evolved within the constraints of phylogenetic legacy and fabricational possibility (and that they may often have been necessary compromises between formally conflicting functions). Even the most effectively "paradigmatic" designs, evolved through natural selection, were therefore bound to be less than "ideal." However, Paul did analyze effectively the differences between Carter and myself in our functional interpretations of zigzag valve edges and tubular external spines in bivalves and brachiopods; he pointed out that in certain respects the morphologies were not strictly comparable, and hence that both sets of interpretations were plausible for their respective cases. In a brief section on richthofeniids (deleted before publication to avoid overlap with Cowen's paper), Paul endorsed some of Grant's reasons for doubting the "flapping" interpretation while rejecting others (Paul, undated draft typescript). The published paper concluded that, notwithstanding Grant's criticisms, the paradigm method itself was fundamentally valid, even though its application might in some cases be problematic and fallible.

In Cowen's paper, duly printed immediately after Paul's, he defended what he now named a "flapping valve" or "rhythmic-flow" feeding mechanism for the richthofeniid brachiopods; like Paul, he also used the case to review the paradigm method itself after more than a decade of debate, and to defend its validity (Cowen, 1975). He showed that Grant's dismissal of analogies with any kind of pump was misconceived, 
since the proposed "flapping" was not a pump-like mechanism, but rather one of rhythmic or "tidal flow" in and out of the richthofeniid shell (rather like our own action in breathing). Cowen argued that a rhythmic mode of feeding that had differed radically from normal ciliary suspension-feeding was not intrinsically improbable or inefficient, since the unusual reef environment of the aberrant brachiopods might well have made unusual categories of floating food available for capture and collection. Cowen responded in detail to Grant's other objections, noting particularly how the morphology of mature richthofeniids would have made any conventional suspension-feeding system highly inefficient, because the inhalant and exhalant water currents could not have been spatially separated. He warned Grant that an "appeal to Occam's razor in this context is a very dangerous gamble." Finally, he pointed out that for all these aberrant organisms "there is no quarrel over data, but only over their interpretation"; he hoped that the future publication of the Texas fossils by Cooper and Grant would enlarge the available "data base" of morphological detail and "allow this particular dispute to be put to rest in a definitive way."

These papers by Paul and Cowen were followed immediately, in the same issue of Lethaia, by a brief "reply" by Grant (1975). Its title, "Methods and conclusions in functional analysis," made it clear that his criticism was intended to reach far beyond the specific case of alleged "flapping" in richthofeniids. He now claimed, rather unconvincingly, that his earlier paper (1972) had not been intended to reject the paradigm method as such, but only to criticize it and to extend it "beyond the structural and mechanistic constraints of the original formulation." Once again, as Gould had noted earlier, "mechanistic" was being treated almost as a dirty word, or at least as an undesirable limitation. "The crux of the matter," Grant claimed, "lies in the evidence": namely, what he had earlier given for the form of the lophophore (as a ptycholophe) in all productide brachiopods, regardless of size and including richthofeniids. Ironically, the one new piece of evidence that he described as invalidating the idea of "flapping" could more readily be interpreted in favor of it. This was a particular specimen of the richthofeniid Hercosestria (the former P. uddeni) in which another more "ordinary" brachiopod (Composita) had grown within, and been confined to, the totally enclosed space between the "trap-door" dorsal valve and the unbroken protective shelly mesh above it (Figure 9). Grant inferred, justifiably, that this brachiopod must have penetrated the mesh and entered that space as a tiny planktonic larva, settled there and then grown to adult size. But he implied that it must have done so while the 


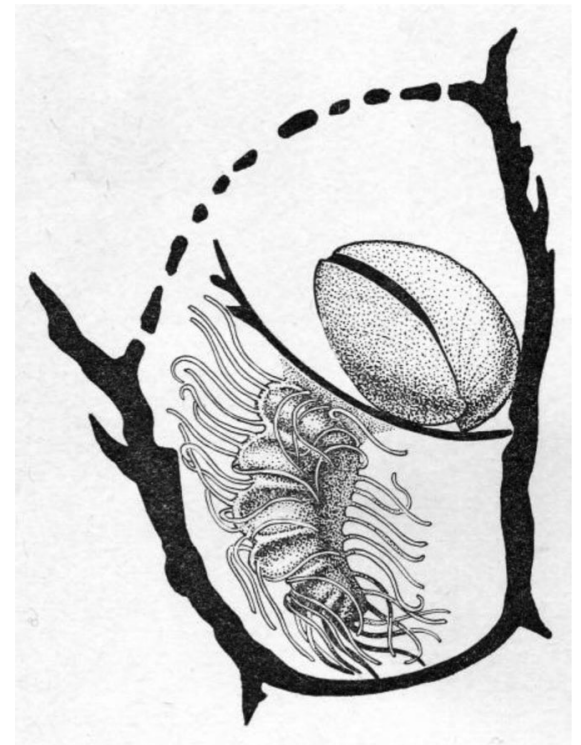

Figure 9. Grant's diagrammatic section of a particular specimen of the richthofeniid Hercosestria cribrosa (formerly named Prorichthofenia uddeni), showing the shell of a more "ordinary" brachiopod (Composita) trapped between the delicate dorsal valve and the arcuate shelly mesh above it (Grant, 1975, Figure 2; by permission of Wiley). Grant assumed, without evidence, that it had lived and grown there while the richthofeniid was still alive. Below the dorsal valve, he depicted hypothetically the (unpreserved) lophophore, but he showed its filaments in a highly unrealistic manner that suggested he did not understand how lophophores function in living brachiopods

richthofeniid was still alive, although it was highly unlikely that any larva would, or indeed could, settle on or attach itself to the live mantle tissue of another brachiopod. Even if it had done so, and the dorsal valve of this particular richthofeniid had been unable to open beyond a small angle, let alone to "flap," the much wider and accurately arcuate form of the shelly mesh immediately above it was left unexplained; certainly no efficient system of steady suspension-feeding currents would have been possible. Grant's interpretation of this one specimen displayed a serious lapse in biological imagination, which was bound to raise doubts about his wider interpretation.

Grant did not send his paper to his critics in advance, and they first read it when all three papers were published together in Lethaia. Cowen responded briefly in a note distributed with offprints of his own paper, underlining the points just summarized, and in particular rejecting Grant's interpretation of the trapped Composita. He concluded, "I stand by my interpretation of the tidal-flow feeding mechanism as the 
best working hypothesis at the moment to explain the complex morphology of these brachiopods" (Cowen, typescript note, 1 July 1975). Cowen's affirmation, combined with Paul's effective defense of the underlying method despite his doubts about the particular case, showed there was still some life in the idea of paradigms.

However, Cooper and Grant were unconvinced. In their huge ongoing monograph on the Permian brachiopods from the Glass Mountains, and before the Lethaia papers appeared, they had already rejected any "pulsating" mechanism for either lyttoniids or richthofeniids. But they did so without any thorough functional analysis of the morphological features that were in contention (Cooper and Grant 1972-1977, pp. 414 [1974], 927-928 [1975]). In fact their specimens were portrayed with a poor quality of reproduction and in a conventional manner that made any such analysis almost impossible. They even illustrated (pl. 127) some of the specimens of Poikilosakos (not from the Glass Mountains) that I had used for my functional interpretation of this probably ancestral lyttoniid (Rudwick, 1971); yet they did not cite that paper - although it had been published in Cooper's own Festschrift - even to reject its conclusions. This seemed to confirm what Gould had earlier identified as Cooper's "antipathy for the likes of you and me," though the reasons for it, scientific or personal or both, remained unclear.

\section{Paleobiology Established, and Paradigms Marginalized}

Since Grant's attack was not answered in published form, some later commentators assumed that he had effectively discredited the paradigm method once and for all. More generally, however, and notably in Germany, it continued to be recognized as an essential component in the functional interpretation of fossil morphology. For example, in a review of "Controlling [Lenkende] and limiting factors in evolution," Wolf-Ernst Reif (1939-2009) noted the crucial role of paradigms in his senior colleague Seilacher's tripartite analysis (Reif, 1975, pp. 143-144). Reif also co-authored a significant review of the "form-function complex," which combined Raup's theoretical morphology with the functional paradigm concept in what was in effect Gould's "quantifunctional" approach; but Reif and his collaborator argued that sufficient attention was still not being given to the third corner of Seilacher's triangle, the "fabricational constraints" [bautechnische Zwänge] that necessarily limit the functional adaptations that can in reality 
evolve, and that go far to explain the prevalence of evolutionary parallelism and convergence (Reif and Robinson, 1975). (That this paper was co-authored by an anglophone scientist was another sign of the growing international influence of Seilacher's school.)

At much the same time an analysis of the foundations of "functional morphological models," this one published in Chicago, judged that my interpretation of zigzag valve edges in brachiopods, as having been protective in function (Rudwick, 1964a), was "the best documented example [of] the paradigm approach"; that it was more predictive for that function than for any other; and that therefore "Rudwick's idea is the one most accepted" (DeMar, 1976). Yet the same author claimed that "evolution interferes with the application of the paradigm approach," because it would not work if a structure serving one function with great efficiency had in fact gradually evolved into serving another with equal efficiency. However, this overlooked my argument that attributing a likely function to a given structure, by comparing it with the paradigm for that function, was methodologically a separate issue from the reconstruction of its phylogenetic origin (Rudwick, 1964b). At least in principle, therefore, it would be possible - without abandoning or even modifying the paradigm method - to trace a seamless evolutionary transition from one function to another, by way of structural intermediates that would represent a shifting balance of compromises between them. Once again the deployment of the paradigm method was being hampered by a misunderstanding of its methodological foundations.

By the mid-1970s, the interpretation of the morphology of invertebrate fossils - whether emphasizing its phylogenetic, functional or fabricational aspects - had become an established component of "paleobiological" research (work on vertebrate fossils remained largely separate, both intellectually and socially, and is beyond the scope of this article). Other and complementary approaches, such as the paleoecological and paleobiogeographical, and of course the evolutionary, were also flourishing. In Continental Europe such Paläobiologie had long been recognized as a distinctive field of research, exemplified by Abel's earlier journal Palaeobiologica. In North America, however, a recognition that these approaches were distinct from the taxonomic and stratigraphical focus of traditional "paleontology" was first signaled unequivocally in 1975, with the foundation of Paleobiology. The original purpose of this new journal was to complement the more traditional Journal of Paleontology by encouraging biologists, and particularly evolutionary biologists, to take a greater interest in what the study of 
fossils could contribute to their science. In the course of a lively discussion among American paleontologists (Sepkoski, 2012, pp. 185-195), Valentine suggested that the proposed journal would get off to a flying start if it had "a first year with a heavy scattering of eminent biologists" among its authors. Among those initially more sceptical, Grant was concerned that it might "encourage speculation that is not firmly based on geological and paleontological documentation"; he may have had in mind "speculation" about the unobservable functions of fossil structures.

An enthusiastic advocate for the new journal was Schopf, who became its first editor (nominally a co-editor). In a draft report on its feasibility, he outlined a broad range of topics that it might cover, anticipating that "most volumes will deal with biological or paleobiological aspects of morphology, biochemistry (organic and inorganic), populations, faunal provinces, communities and ecosystems" (Sepkoski, 2012, p. 190). This list was later printed in the inaugural issue of $P a$ leobiology as a brief statement of editorial policy; it is notable that morphology was given first place. Valentine's hope that the first authors might include some heavyweight evolutionary biologists was not fulfilled, but the papers in the first issue did exemplify a broad and inclusive conception of the science. The very first paper, co-authored by Gould, was a computer-aided analysis of the "theoretical morphology" of some enigmatic Paleozoic fossils (receptaculitids) of highly uncertain affinities (Gould and Katz, 1975). Other papers dealt with the functional morphology of both living and fossil organisms: Stanley, for example, reported on his "experimental analysis of burrowing" to explain "why clams have the shape they have" (Stanley, 1975). And the new quantitative or nomothetic paleontology was represented by Raup's paper on "taxonomic survivorship curves" (Raup, 1975), and by a paper by him and the others in the "MBL" group, in which "rates of evolution" were evaluated by the quantitative measure of the number of morphological terms needed by paleontologists to describe fossils of different major groups (Schopf et al., 1975). Here morphology was quantified in the service of evolutionary theory but, once again, shorn of its functional or adaptive significance.

Nonetheless the functional approach still held its own. In 1977 Raup became the new president of the Paleontological Society and - as he admitted, or perhaps boasted - the first who had never described or named any new species of fossil. But in an irenical presidential address he insisted that any theory proposed by himself "and other so-called paleobiologists" should always be based on the kind of morphological 
description which members of the Society traditionally practiced: the two kinds of research were not antagonistic but complementary. On the theme he chose for his address, "The extinction problem," he emphasized the sheer universality of extinction, and that it did not imply any deficiency in the organisms affected: "only good functional morphology could tell us that" (Raup, 1978, p. 522).

As the decade ended, a pair of brief but effective articles in a new and substantial Encyclopedia of Paleontology (Fairbridge and Jablonski, 1979) showed that the foundations of morphology had not been forgotten. The first article, on "Morphology, Constructional," summarized Seilacher's tripartite conception of morphology, explained the heuristic role of my "mechanical paradigm, an optimum model of maximal efficiency," and noted how many papers inspired by Seilacher's work had been published since the start of the decade (Thomas, 1979). In the second article, on "Morphology, Functional," Cowen summarized a range of functional interpretations of fossils; he gave a balanced assessment of the paradigm method, its potential and its problems, judging that it was "chiefly useful in promoting clarity of thought in functional analysis" (Cowen, 1979).

In the same year, however, this still quite prominent role for functional morphology as an essential component of "paleobiology" was radically questioned by Gould, in a paper nominally co-authored with his senior Harvard colleague Richard Lewontin (1929-), which was announced as a "critique of the adaptationist programme" (Gould and Lewontin, 1979). Gould's often iconoclastic ideas, combined with his attractive prose style, had propelled him within a few years into a position of controversial prominence among evolutionary biologists; and his monthly articles in Natural History (from 1974), many of them subsequently reprinted in book form (first in Gould, 1977), were making him equally well known as a "public intellectual." Unsurprisingly, therefore, his paper on "The spandrels of San Marco" was as influential and as controversial as his earlier paper (with Eldredge) on punctuated equilibrium.

"The spandrels of San Marco" - the enigmatic title of the paper was all the more provocative for being published in the highly respectable Proceedings of the Royal Society in London - opened with an extended analogy drawn, as often in Gould's writing, from his own wide cultural interests. In any cruciform church built in the Byzantine tradition (the cathedral in Venice was cited just because it is widely known), the central circular dome is supported on four semicircular arches; the geometrically inevitable intervening spaces are filled with 
vaulting in the form of four concave triangular spandrels. These four spandrels were commonly used, as they are in St Mark's, to display prominent images of the four Evangelists. But no art historian would claim that spandrels were designed for that purpose: as Gould rightly put it, spandrels are "necessarily architectural by-products of mounting a dome on rounded arches." However, this analogy, with its obvious allusion to the bautechnischer or fabricational factor in Seilacher's analysis, was then used by Gould to dismiss all interpretations of morphology that anticipated finding adaptive significance in any and every feature of an organism. This "adaptationist programme," as Gould termed it, was criticised scornfully with an allusion to Voltaire's ever-optimistic Dr Pangloss: in the article's title it was described as "the Panglossian paradigm" (the latter word being used here, of course, in Kuhn's sense). This was coupled with a repeated reference to "adaptive stories," with its obvious allusion to Rudyard Kipling's "Just-So Stories" for children, on "How the Leopard got its Spots" and other similarly entertaining tales.

My interpretation of zigzags on the valve edges of fossil brachiopods (Rudwick, 1964a) had the dubious distinction of being cited in first place as an example of such "adaptive stories": it was dismissed as the product of a vacuous policy of "If one adaptive argument fails, try another." Surprisingly, in view of Gould's previously enthusiastic acceptance of the method of paradigms (in my sense of the word), this ignored its heuristic power to test putative functions and to infer that one was more likely than another; and so it also ignored the capacity of the method to generate progressively better adaptive interpretations. Not all "adaptive stories" were equally plausible, so any prescription to "try another" if the first failed - though this was not phrasing I had ever used - was a potentially productive strategy, not a fallacious dead end.

There was a serious flaw in Gould's architectural analogy, which was not adequately acknowledged at the time. The fourfold spandrels of any cruciform Byzantine church were indeed designed - and well adapted to complete the vaulting over the interior and to strengthen the whole structure. But once they were there as an integral part of the structure, they were equally well adapted to display the fourfold imagery of the four Evangelists, as an integral part of an iconography designed to express symbolically the cosmic meaning of the whole building (with, for example, the "Christ Pantocrator" often sited at the central point of the dome above the spandrels, and at the unique center of the iconography). Gould's use of an analogy with spandrels failed to acknowledge that one and the same morphological feature can readily serve two 
functions simultaneously and with equal efficacy, if their respective paradigms coincide or at least overlap. As with domes and spandrels, the historical origin or phylogeny of the features is a separate question: one feature and function may well have preceded, and been a necessary structural precondition for, another feature and function.

Gould's "Spandrels" paper was a plea, well argued although provocatively expressed, for more attention to be given by biologists (including paleobiologists) to the fabricational constraints that limit the "perfection" of adaptations produced under natural selection. But the paper's attractive and accessible style was such that its side effect, intended or not, was to devalue all attempts to identify the functions that organic structures may have served in the unobservable deep past. Gould's demotion and derisive near-dismissal of the functional or adaptive "aspect" of Seilacher's tripartite analysis had a profoundly damaging impact on paleobiology in the following decade or more. This was hardly compensated by the positive impact of his emphasis, following Seilacher, on the combination of phylogenetic and fabricational "aspects." The intellectual or biographical reasons for Gould's dramatic change of mind on the place of functional morphology in paleobiology remain somewhat obscure, but were certainly related in part to his changing stance in contemporary debates among evolutionary theorists, which highlighted putatively non-functional or non-adaptive aspects of morphology (Dresow, 2017).

The year after the "Spandrels" paper was published, Gould made his critique of functional morphology more explicit in an article in Paleobiology that was his contribution to a series on the "status of paleontology [in] 1980"; he warned at the start that "This paper is not a review article; it is a partisan statement." In "The promise of paleobiology as a nomothetic evolutionary discipline" (Gould, 1980) he presented his case, even more forcefully than before, for rejecting the traditional idiographical goals of paleobiology in favor of the nomothetic: "much paleobiological work continues in the "empirical law" tradition - it accumulates cases in the hope that some useful generality will emerge." He claimed that this hope was in vain, as shown by the example - which he sandwiched between those of "community reconstruction" (i.e., synecology) and "biostatistics" - of "mechanistic functional morphology" (Gould, 1980, p. 101):

The flowering of functional morphology has yielded a panoply of elegant individual examples and [i.e., but] few principles beyond the unenlightening conclusion that animals work well... But I think that higher hopes were once held (Rudwick, 1964[b]). I, at least, 
once harbored the naïve [sic] belief that a simple enumeration of more and more cases would yield new principles for the study of form (Gould, 1970).... I suspect that functional morphology will fulfil its promise [only] when it probes the situations in which animals are not well designed - developmental, phyletic, and architectural [i.e., fabricational] constraints as marks of history (Seilacher, 1972; Gould and Lewontin, 1979). As a key issue, why is morphological space so sparsely populated, but so clumped where it is occupied? How much of clumping and non-occupation reflect [respectively] good and untenable design, how much the constraints of genealogy?

Gould's reference to Raup's conception of a potential "morphospace" only partially filled with real organisms, past or present, was strangely blind to the role of functional morphology in explaining - with some success, as Raup certainly recognized - why, within the "constraints of genealogy," organisms are "clumped" as they are. In other words, he failed to acknowledge that the boundaries between the "occupied" and "sparsely populated" parts of a morphospace could only be explained by attending not only to the constraints that limit optimality of function but also to the pressures of natural selection towards attaining that optimality as fully as possible.

In this context Gould specifically criticized the paradigm method, and used a past tense that implied it was already invalidated and obsolete. While conceding that "it clarified procedure and directed attention to the central [sic] problem of non-optimality," he claimed that "It foundered on the difficulty of specifying function a priori (in order to know what paradigm to construct)." This, however, was tantamount to asserting that any scientific hypothesis would be invalidated, even before its predictions were subjected to empirical test, if it could not be selected in advance from among other and rival hypotheses. Of course, such a procedure would not be considered acceptable in any other scientific situation. How I had first conceived of zigzag valve edges as possibly protective devices - by trying hard to imagine "what it is like to be a brachiopod," even to the point of dreaming of being one! - was irrelevant to my attempt to test the idea by analyzing the geometry of zigzag slits, both paradigmatic and real, and then concluding that a protective function was far superior in explanatory value to its suggested rivals.

Before writing this review Gould had asked twenty other paleontologists for their opinions on several current trends in the science; among his respondents (to name only those already mentioned here) 
were Cooper, Cowen, Grant, Hallam, Raup, Schopf, and Valentine (Gould, 1980, p. 116). On functional morphology, Gould reported that "Supporters cite improved understanding of how individual taxa and broader groups functioned; debunkers deplore the speculative quality of some work, based on naïve (and downright false [sic]) assumptions that everything is adaptive and that natural selection produces optimal design." On this crucial issue, Gould recorded that "My own increasingly ambivalent feelings about standard functional morphology arise from its failure to generate new theory," in that it had not developed beyond the basic premise that all organisms are well adapted: "The theme of good design has not been productive of any new or general insight." The only way to escape from this dead end, he concluded, was to reject the "rigid adaptationist program" and to accept that "Organisms are not optimizing machines; they are historical objects, constructed by inherited Baupläne, modes of development, and mechanical properties of building materials" (p. 111). He did not explain, let alone justify, this claim that the historical legacy and ontogeny of the organism, and the fabricational constraints on its anatomy, are incompatible with the functional optimizing of its organic design - within those sets of limitations - under natural selection.

Gould's critique of the "adaptationist program" had less impact outside the United States. In 1980, for example, the Paläontologische Gesellschaft in Germany commissioned a series of authoritative reviews of recent research; and the very first, edited by Reif of Tübingen, was on Funktionsmorphologie (Reif, 1981a). Reif's own introduction, on "Concepts and methods of functional morphology," included a section on the paradigm method. Here he noted that since 1975, when the wellknown trio of papers by Paul, Cowen and Grant (already described here) was published, "the problem has vanished from the literature: wrongly, for it was just this discussion that resolved many misunderstandings" (Reif, 1981b, p. 15, my translation). The following year Reif enlarged on this "problem" in a paper that described functional morphology as lying uncomfortably "on the procrustean bed of the neutralism-selectionism debate" in evolutionary theorizing (Reif, 1982): this identified what was apparently the major factor in Gould's change of mind about the paradigm method (Dresow, 2017). Reif noted how the "constructional" approach to morphology, as pioneered by Seilacher, had emphasized the intrinsic constraints on the evolutionary optimizing of functional structures; at the same time, however, he identified functional inference as "one of the most important keys to paleoauteocology," which in turn was "one of the most constitutive fields of 
paleobiology" (Reif, 1982, p. 53). He judged that in this respect mechanistic analogues were of greatest value: "The focal point here is, of course, Rudwick's (1964[b]) paradigm method." That "the discussion has virtually come to a stop since 1975 " was again attributed to the growing appreciation of the phylogenetic and fabricational constraints on functional optimality: "Rudwick was aware of this and formulates it in an admittedly not very powerful way, but since Rudwick this aspect has won more attention" (Reif, 1982, pp. 53-54). In other words, Reif attributed the decline in the relative prominence of functional reconstructions in paleobiology - and hence also in the use of the paradigm method - to the perceived importance of Seilacher's other two "aspects." However, this did not address the continuing need to find an adequate way in which all three "aspects" or "factors" could be related and integrated.

Immediately following Reif's quite positive evaluation, the same German journal printed "A critical re-evaluation of the paradigm method of constructional inference" (Signor, 1982). Its author noted that "the paradigm method of functional analysis was well received and is now commonly employed." But it was said to be "fundamentally flawed by its crucial assumption that a single optimal solution (the paradigm) is the predictable outcome of evolution by natural selection." This however assigned roles to prediction and singularity that were altogether absent from the original formulation of the method: for example, the multiplicity and evidently polyphyletic origin of zigzag valve edges and other putatively protective devices in brachiopods clearly illustrated how an abstract geometrical paradigm was bound to take many concrete forms, depending on the materials available during ontogeny and as the legacy of phylogeny (Rudwick, 1964a). Regrettably, this author's critique, like some others, showed an inadequate grasp of the empirical details of the examples that had been offered in illustration of the method: in this case, only my analysis of Prorichthofenia (Rudwick, 1961) was cited, and even this was mentioned only in passing, not criticized in detail.

\section{Conclusion}

I have suggested that Gould's "Spandrels" paper of 1979, with its striking volte-face on the value of functional morphology in general and the paradigm method in particular, was deeply deleterious to this kind of paleobiology, because by that time Gould himself had become such 
an influential "public intellectual" that his word was widely taken to be the truth on any matter of evolutionary biology. As Cowen recalls, "Gould had a dreadful impact on invertebrate functional studies. At least, I blame him: NSF [National Science Foundation] funding for invertebrate functional projects simply dried up. Functional morphology went on in Canada, Britain and Europe, of course" (Cowen to Rudwick, 4 September 2016). In the rather separate world of vertebrate paleontology, the possible functions of, for example, the morphological features of dinosaurs had never faded from the attention of the relevant scientists: on both sides of the Atlantic the "ways of life" of such animals continued to be the subject of lively scientific debate, and were often reconstructed in striking museum exhibits (and later in animated television programs), which fascinated the general public.

The paradigm method itself continued to be reviewed explicitly from time to time, at least to the end of the century. For example, within a comprehensive collection of essays on the Functional Morphology of the Invertebrate Skeleton (Savazzi, 1999), Paul returned to the fray to defend once again the validity and value of "paradigms" in paleobiology. And he asked, significantly, "I wonder why it is [that] the paradigm method has attracted so much criticism" (Paul, 1999, p. 28), though at the time he did not suggest an answer.

At the start of the new millennium, the first quarter-century of $\mathrm{Pa}$ leobiology was celebrated with a special book-length issue titled Deep Time (Erwin and Wing, 2000). Its editors emphasized how biologists still needed to take more seriously the temporal dimension of the complex history of life on Earth, which only paleontology could supply. The volume was an effective display of what "paleobiology" now had to offer, as distinct from the traditional kinds of paleontology. Among many fine essays, one with the informative subtitle "functional analysis in paleobiology" had a striking main title: "Invention by evolution" (Plotnik and Baumiller, 2000). This signalled its authors' recognition that "mechanistic" thinking remained crucially important - though not unproblematic - in the functional analysis of fossils and their interpretation in terms of the adaptations generated in the course of evolution. This thorough survey of the state of functional analysis at the start of the new century showed not only how much valuable work was continuing to be published, but also how far the analysis of invertebrate fossils had come to be integrated with that of vertebrates (which for practical reasons have been beyond the scope of the present article). So for example the paradigm method was said to have been largely supplanted by - or, rather, subsumed within - the methodology of 
"biomechanics," with many of its best examples drawn from the mechanical analysis of the skeletons and musculature of living and fossil vertebrates.

However, this assimilation of paradigms into biomechanics had the inadvertent effect of glossing over the crucial epistemological contrast between paleontology and neontology. As this brief history of the paradigm method has illustrated, distinctive epistemological problems are inherent in the functional interpretation of fossil organisms, simply because they cannot be observed alive or made the subjects of direct experiment. The problems of understanding the biomechanics of flying, for example, are not the same for pterosaurs as they are for bats; the problems of reconstructing the hydrodynamics of feeding mechanisms in aberrant Permian brachiopods are not the same as they are for observing those of brachiopods now alive in New Zealand.

By the turn of the century, much of the earlier work described in the present article and its predecessor (Rudwick, 2017) had fallen out of sight: such are the brief half-lives of most scientific papers. For example, in the essay just mentioned, my methodological analysis of paradigms (Rudwick, 1964b) was the only one of my publications to survive among the sources cited. This was a pity, not for any personal reasons but much more because a closer reference back to my own and related papers on specific cases of functional analysis might have helped avoid the widespread but mistaken impression that a paradigm design was by definition one that was "ideally efficient," or else that it was merely a source of imaginative ideas about possible functions. It might have focussed attention instead on the capacity of the paradigm method to provide testable models of what the optimizing of a function, under natural selection, might be expected to have generated in any specific circumstances of phylogenetic legacy and fabricational constraint.

In conclusion, my frequent use of the phrase "organic design" in relation to the paradigm method may be thought to disclose the hitherto barely mentioned "elephant in the room": namely the influence, both positive and negative, of the idea of "design" in the biological sciences. Positively, the concept of "organic design" has unquestionably been of outstanding value in the development of functional morphology ever since the time of Cuvier in the early nineteenth century, and not least in the influence of D'Arcy Thompson's work in the early to mid-twentieth century. Negatively, its early historical association with William Paley's deistic "argument from design" may have inhibited later paleontologists from exploring wholeheartedly the possible role of "organic design" in fossil organisms (it has sometimes, particularly in the anglophone 
world, mistakenly been taken to be incompatible with evolutionary thinking). This factor may have been aggravated by the rise of fundamentalistic creationism - and more recently of "intelligent design" ideas - to cultural and even political prominence in the United States (though not in Europe). But I do not recall that back in the 1960s and 1970s my emphasis on "organic design," derived in my case particularly from my early personal contact with Pantin (who was no fundamentalist!), was ever criticized for giving comfort to creationists.

Gould's dramatic change of mind about the value of the paradigm method, switching from enthusiastic endorsement to somewhat derisory dismissal, came much too late to have had any influence on my own earlier (and, at the time, quite difficult) decision to switch my teaching and research in mid-career from paleontology to the history of this and related sciences. I followed Gould's later work and that of my other former colleagues with very great interest but, inevitably, with declining involvement. Conversely, Gould was well aware of my historical research, mentioned it in his essays, and published reviews of some of it with evident appreciation. Certainly we remained personal friends. After what turned out to be our last meeting before his tragically early death, he wrote: "Great to see you. Always so many good ideas and conversations. To quote an old favorite line: I always feel as though half my ideas come out of Rudwick's brain" (Gould to Rudwick, 28 August [1998]). The allusion to Darwin's famous remark to his mentor Charles Lyell was flattering to me and hardly modest about himself; but its reference was probably as much to my historical research as it was to my earlier work in paleobiology.

\section{Acknowledgements}

As in the article to which this is the sequel, it is a great pleasure to thank David Sepkoski for first urging me to attempt this piece of twentieth-century historiography. I also thank Richard Cowen for giving me masses of fascinating first-hand information on these and later developments in paleobiology; Euan Clarkson, for giving me images from his early articles; and Chris Paul, for filling in some important gaps in my recollections. Simon Conway Morris, Martina Kölbl-Ebert and Paolo Tamborini also read a draft of this article and gave me many valuable suggestions for its improvement. In checking the dates of the scientists mentioned here by name (in my opinion, years-of-birth are important for giving a sense of the ages and genera- 
tions of those involved), I have been saddened to realise how, by not tackling this research project earlier in my own career, I have missed the opportunity to discuss the drama with some of its most important players: particularly my friends the late Dave Raup and Steve Gould, but also those I never had the pleasure of meeting, particularly the late Dolf Seilacher. I just hope they would have approved of my account of their research, brief though it is, even though perhaps they might not have agreed with all my conclusions.

\section{Open Access}

This article is distributed under the terms of the Creative Commons Attribution 4.0 International License (http://creativecommons.org/ licenses/by/4.0/), which permits unrestricted use, distribution, and reproduction in any medium, provided you give appropriate credit to the original author(s) and the source, provide a link to the Creative Commons license, and indicate if changes were made.

\section{References}

Abel, Othenio. 1912. Grundzüge der Paläobiologie der Wirbelthiere. Stuttgart: E. Schweizerbart.

Ager, Derek V. 1963. Principles of Paleoecology: An Introduction to the Study of How and Where Animals and Plants Lived in the Past. New York: McGraw-Hill.

- 1965 "The Adaptations of Mesozoic Brachiopods to Different Environments." Palaeogeography, Palaeoclimatology, Palaeoecology 1: 143-172.

Beerbower, James R. 1960. Search for the Past: An Introduction to Paleontology. Englewood Cliffs: Prentice-Hall.

Briggs, Derek E. G. (ed.). 2005. Evolving Form and Function: Fossils and Development. New Haven: Peabody Museum.

-2005b "Seilacher on the science of form and function." E. G. Briggs (ed.), Evolving Form and Function. New Haven, CT: Yale University Press, pp. 3-24.

Carter, Robert M. 1968. "Functional Studies on the Cretaceous Oyster Arctostrea." Palaeontology 11: 458-485.

Clarkson, Euan N. K. 1966a. "Schizochroal Eyes and Vision in Some Silurian Acastid Trilobites." Palaeontology 9: 1-29.

-1966b "Schizochroal Eyes and Vision in Some Phacopid Trilobites." Palaeontology 9: 464-487.

Clarkson, Euan N. K. and Levi-Setti, R. 1975. "Trilobite Eyes and the Optics of Descartes and Huygens." Science 254: 663-667.

Cooper, G. Arthur and Grant, Richard E. 1969. "New Permian Brachiopods from West Texas." Smithsonian Contributions to Paleobiology 1: 1-20. 
1972-1977 "Permian brachiopods of West Texas." Smithsonian Contributions to Paleobiology 14, 15, 19, 21, 24, 32.

Cowen, Richard. 1970. "Analogies Between the Recent Bivalve Tridacna and the Fossil Brachiopods Lyttoniacea and Richthofeniacea." Palaeogeography Palaeoclimatiology Palaeoecology 8: 329-344.

- 1975 "“Flapping Valves' in Brachiopods." Lethaia 8: 23-29.

1979 "Morphology, Functional." R. W. Fairbridge and D. Jablonski (eds.), Encyclopedia of Paleontology. Dowden: Hutchinson and Ross, pp. 487-492.

Cowen, Richard and Kelley, John S. 1976. "Stereoscopic Vision Within the Schizochroal Eye of Trilobites." Nature 261: 130-131.

DeMar, R. E. 1976. "Functional Morphological Models: Evolutionary and Non-evolutionary." Fieldiana, Geology 33: 339-354.

Dresow, Max W. 2017. "Before Hierarchy: The Rise and Fall of Stephen Jay Gould's First Macroevolutionary Synthesis." History and Philosophy of the Life Sciences 39. doi:10.1007/s40656-017-0133-6.

Dutro, J. Thomas, Jr. (ed.). 1971. Paleozoic Perspectives: A Paleontological Tribute to G. Arthur Cooper. Washington, D. C.: Smithsonian Institution Press [Smithsonian Contributions to Paleobiology 3].

Eldredge, Niles. 1971. "The Allopatric Model and Phylogeny in Paleozoic Invertebrates." Evolution 25: 156-167.

1972 "Systematics and Evolution of Phacops rana (Green 1832) and Phacops iowensis Delo (1835): Trilobita in the Middle Devonian of North America." Bulletin of the American Museum of Natural History 47: 45-114.

Eldredge, N. and Gould, S. J. 1972. "Punctuated Equilibria: An Alternative to Phyletic Gradualism." T. J. M. Schopf (ed.), Models in Paleobiology. San Francisco: Freeman Cooper \& Co, pp. 83-115.

Erwin, Douglas H. and Wing, Scott L. (eds.). 2000. Deep Time: Paleobiology's Perspective. Paleobiology 26(4), supplement.

Fairbridge, Rhodes W. and Jablonski, David (eds.). 1979. The Encyclopedia of Paleontology. Stroudsburg (Pennsylvania): Dowden Hutchinson and Ross.

Gould, Stephen Jay. 1966. "Allometry and Size in Ontogeny and Phylogeny." Biological Reviews 41: 587-640.

- 1968 "Ontogeny and the Explanation of Form: An Allometric Analysis." Donald

B. Macurda, Jr. (ed.), Growth and Development. Knoxville, TN: Paleontological Society, pp. 81-93.

- 1970 "Evolutionary Paleontology and the Science of Form." Earth Science Reviews 6: 77-119.

- 1971a "D'Arcy Thompson and the Science of Form." New Literary History 2: 229-258.

1971b "Tübingen Meeting on Form.” Journal of Paleontology 45: 1042-1043.

1971c "Muscular Mechanics and the Ontogeny of Swimming in Scallops." Palaeontology 14: 61-94.

1977 Ever Since Darwin. New York:W. W. Norton.

- 1980 "The Promise of Paleobiology as a Nomothetic Evolutionary Discipline." Paleobiology 6: 96-118.

1984 “The Life and Work of T. J. M. Schopf (1939-1984).” Paleobiology 10: 280285. 
Gould, Stephen Jay and Katz, Michael. 1975. "Disruption of Ideal Geometry in the Growth of Receptaculitids: A Natural Experiment in Theoretical Morphology." Paleobiology 1: 1-20.

Gould, Stephen Jay and Lewontin, R. C. 1979. "The Spandrels of San Marco and the Panglossian Paradigm: A Critique of the Adaptationist Programme." Proceedings of the Royal Society of London B 205: 581-598.

Grant, Richard E. 1963. "Unusual Attachment of a Permian Linoproductid Brachiopod." Journal of Paleontology 37: 137-140.

1966 "Spine Arrangement and Life Habits of the Productoid Brachiopod Waagenoconcha." Journal of Paleontology 40: 1063-1069.

— 1968 "Structural Adaptation in Two Permian Brachiopod Genera, Salt Range, West Pakistan." Journal of Paleontology 42: 1-32.

1971 "Brachiopods in the Permian Reef Environment of West Texas." Proceedings of the North American Paleontological Convention 1969 J: 1444-1481.

1972 "The Lophophore and Feeding Mechanism of the Productidina (Brachiopoda)." Journal of Paleontology 46: 213-248.

1975 "Methods and Conclusions in Functional Analysis: A Reply." Lethaia 8: 3133.

Hallam, Anthony 1967. "The Bearing of Certain Palaeozoogeographic Data on Continental Drift." Palaeogeography, Palaeoclimatology, Palaeoecology 3: 201-241.

1968 "Morphology, Palaeoecology and Evolution of the Genus Gryphaea in the British Lias." Philosophical Transactions of the Royal Society of London B 254: 91128.

Harland, W. Brian, et al. (eds.). 1967. The Fossil Record. London: Geological Society. Joysey, Kenneth A. 1959. "The Evolution of the Liassic Oysters Ostrea-Gryphaea." Biological Reviews 34: 297-332.

Kuhn, Thomas S. 1962. The Structure of Scientific Revolutions. Chicago: University of Chicago Press.

Kullman, J. and Scheuch, J. 1970. "Wachstums-Änderungen in der Ontogenese paläozoischer Ammonoiden." Lethaia 3: 397-412.

Laubichler, Manfred D. and Niklas, Karl J. 2009. "The Morphological Tradition in German Paleontology: Otto Jaekel, Walter Zimmermann, and Otto Schindewolf." D. Sepkoski and M. Ruse (eds.), Paleobiological Revolution. Chicago: University of Chicago Press, pp. 279-300.

Macurda, Donald B., Jr. (ed.). 1968. Paleobiological Aspects of Growth and Development. Knoxville, TN: Paleontological Society, Memoir 2 [Journal of Paleontology 42, Supplement].

Moore, Raymond C. (ed.). 1965-1971. Treatise on Invertebrate Paleontology [first edition]. Boulder: Geological Society of America and University of Kansas Press.

Nairn, A. E. M. (ed.). 1964. Problems in Paleoclimatology. London: Interscience Publications.

Nichols, David. 1959a. "Changes in the Chalk Heart-Urchin Micraster Interpreted in Relation to Living Forms." Philosophical Transactions of the Royal Society of London, B 242: 347-437.

— 1959b "Mode of Life and Taxonomy in Irregular Sea-Urchins." Systematics Association Publications 3 [Function and Taxonomic Importance]: 61-80.

Pantin, Carl F A. 1951. “Organic Design.” Advancement of Science 30: 138-150. 
Paul, Christopher R. C. 1967. "The Functional Morphology and Mode of Life of the Cystoid Pleurocystites E. Billings 1854." Symposia of the Zoological Society of London 20: 105-123.

1968 "The Morphology and Function of Dichoporite Pore-Structures in Cystoids." Palaeontology 11: 697-730.

1972 "Morphology and Function of Exothecal Pore-Structures in Cystoids." Palaeontology 15: 1-28.

1975 “A Reappraisal of the Paradigm Method of Functional Analysis in Fossils." Lethaia 8: 14-21.

1999 "The Paradigm Method." E. Savazzi (ed.), Functional Morphology of the Invertebrate Skeleton. Chichester: Wiley, pp. 25-28.

Philip, G. M. 1962. "The Evolution of Gryphaea." Geological Magazine 99: 327-344.

Plotnik, Roy E. and Baumiller, Tomasz K. 2000. "Invention by Evolution: Functional Analysis in Paleobiology.” D. H. Erwin and S. L. King (eds.), Deep Time, pp. 305323.

Raup, David M. 1962. "Computer as Aid in Describing Form in Gastropod Shells." Science 138: 150-152.

1966 "Geometric Analysis of Shell Coiling: General Problems." Journal of Paleontology 40: 1178-1190.

1967 "Geometric Analysis of Shell Coiling in Ammonoids." Journal of Paleontology 41: 43-65.

1968 "Theoretical Morphology of Echinoid Growth.” Donald B. Macurda, Jr. (ed.), Growth and Development. Knoxville, TN: Paleontological Society, pp. 50-63.

1972 “Approaches to Morphological Analysis." T. J. M. Schopf (ed.), Models in Paleobiology. San Francisco: Freeman Cooper \& Co, pp. 28-45.

1975 “Taxonomic Survivorship Curves and Van Valen's Law.” Paleobiology 1: 8296.

— 1978 "Approaches to the Extinction Problem." Journal of Paleontology 52: 517523.

Raup, David M. and Gould, Stephen J. 1974. "Stochastic Simulation and the Evolution of Morphology - Towards a Nomothetic Paleontology." Systematic Zoology 23: 305-322.

Raup, David M., Gould, Stephen J., Schopf, Thomas J. M. and Simberloff, Daniel S. 1973. "Stochastic Models of Phylogeny and the Evolution of Diversity." Journal of Geology 81: 525-542.

Raup, David M. and Michelson, Arnold. 1965. "Theoretical Morphology of the Coiled Shell." Science 147: 1294-1295.

Raup, David M. and Seilacher, Adolf. 1969. "Fossil Foraging Behavior: Computer Simulations." Science 166: 994-995.

Raup, David M. and Stanley, Steven M. 1971. Principles of Paleontology. San Francisco: W. H. Freeman [2nd ed., 1978].

Reif, Wolf-Ernst. 1975. "Lenkende und limitierende Faktoran in der Evolution." Acta Biotheoretica 24: 136-162.

Reif, Wolf-Ernst. (ed.). 1981a. Funktionsmorphologie. München: Paläontologische Gesellschaft [Paläontologische Kursbücher 1].

Reif, Wolf-Ernst. 1981b. "Konzepte und Methoden der Funktionsmorphologie." WolfErnst Reif (ed.), Funktionsmorphologie. München: Paläontologische Gesellschaft [Paläontologische Kursbücher 1]: pp. 11-24. 
Reif, Wolf-Ernst. 1982. "Functional Morphology on the Procrustean Bed of the Neutralism-Selectionism Debate - Notes on the Constructional Morphology Approach." Neues Jahrbuch der Geologie und Paläontologie, Abhandlungen 164: 46-59.

Reif, Wolf-Ernst and Robinson, Jane A. 1975. "Geometric Relationships and the FormFunction Complex: Animal Skeletons [Konstruktionsmorphologie Nr. 31]." Neues Jahrbuch der Geologie und Paläontologie, Monatshefte 1975: 304-309.

Rudwick, Martin J. S. 1959. "The Growth and Form of Brachiopod Shells." Geological Magazine 96: 1-24.

1961 "The Feeding Mechanism of the Permian Brachiopod Prorichthofenia." Palaeontology 3: 450-471.

1962 "Filter-Feeding Mechanisms in Some Brachiopods from New Zealand." Journal of the Linnean Society of London, Zoology 44: 592-615.

— 1964a "The Function of Zigzag Deflexions in the Commissures of Fossil Brachiopods." Palaeontology 7: 135-171.

— 1964b "The Inference of Function from Structure in Fossils." British Journal for the Philosophy of Science 15: 27-40.

1965 "Sensory Spines in the Jurassic Brachiopod Acanthothiris." Palaeontology 8: 604-617.

1968 "Some Analytic Methods in the Study of Ontogeny in Fossils with Accretionary Skeletons." Donald B. Macurda, Jr. (ed.), Growth and Development. Knoxville, TN: Paleontological Society, pp. 35-49.

1970 Living and Fossil Brachiopods. London: Hutchinson.

1971 "The Functional Morphology of the Pennsylvanian Oldhaminoid Brachiopod Poikilosakos." J. Thomas Dutro, Jr. (ed.), Paleozoic Perspectives: A Paleontological Tribute to G. Arthur Cooper. Washington, D. C.: Smithsonian Institution Press [Smithsonian Contributions to Peleobiology 3], 267-282.

2008 Worlds Before Adam: The Reconstruction of Geohistory in the Age of Reform. Chicago:University of Chicago Press.

2017 "Functional Morphology in Paleobiology: Origins of the Method of Paradigms." Journal of the History of Biology. doi:10.1007/s10739-017-9478-4.

Rudwick, Martin J. S. and Cowen, Richard C. 1968. "The Functional Morphology of Some Aberrant Strophomenide Brachiopods from the Permian of Sicily." Bollettino della Società Paleontologica Italiana 6 ['1967']: 113-176.

Russell, E. S. 1916. Form and Function: A Contribution to the History of Animal Morphology. London: John Murray.

Savazzi, Enrico (ed.). 1999. Functional Morphology of the Invertebrate Skeleton. Chichester: Wiley.

Schopf, Thomas J. M. (ed.). 1972a. Models in Paleobiology. San Francisco: Freeman, Cooper.

- 1972b "Varieties of Paleobiological Experience." T. J. M. Schopf (ed.), Models in Paleobiology. San Francisco: Freeman Cooper \& Co, pp. 8-25.

Schopf, Thomas J. M., Raup, David M, Gould, Stephen Jay and Simberloff, S. 1975. "Geonomic Versus Morphologic Rates of Evolution: Influence of Morphologic Complexity." Paleobiology 1: 63-70.

Seilacher, Adolf. 1953a. "Studien zur Palichnologie. I. Über die Methoden der Palichnologie." Neues Jahrbuch der Geologie und Paläontologie, Abhandlungen 96: 421-452.

1953b "Studien zur Palichnologie. II. Die fossile Ruhespuren (Cubichnia)." Neues Jahrbuch der Geologie und Paläontologie, Abhandlungen 98: 87-124. 
1968 "Form and Function of the Stem in a Pseudoplanktonic Crinoid (Seirocrinus)." Palaeontology 11: 275-282.

- 1970 “Arbeitskonzept zur Konstruktions-Morphologie.” Lethaia 3: 393-396.

1972 "Divaricate Patterns in Pelecypod Shells." Lethaia 5: 325-343.

1979 "Constructional Morphology of Sand Dollars." Paleobiology 5: 191-221.

2012 Rereading the Fossil Record: The Growth of Paleobiology as an Evolutionary Discipline. Chicago: University of Chicago Press.

Sepkoski, David. 2005. "Stephen J. Gould, Jack Sepkoski and the 'Quantitative Revolution' in American Paleobiology." Journal of the History of Biology 38: 209 237.

Seilacher, Adolf and Ruse, Michael (eds.). 2009. The Paleobiological Revolution: Essays on the Growth of Modern Paleontology. Chicago: University of Chicago Press.

Signor, Ph.W. 1982. "A Critical Re-evaluation of the Paradigm Method of Constructional Inference." Neues Jahrbuch der Geologie und Paläontologie, Abhandlungen 164: 59-63.

Stanley, Steven M. 1968. "Post-Paleozoic Adaptive Radiation of Infaunal Bivalve Molluscs - A Consequence of Mantle Fusion and Siphon Formation." Journal of Paleontology 42: 214-229.

- 1970 "Relation of Shell Form to Life Habits of the Bivalvia (Mollusca)." Geological Society of America, Memoir 125: 1-296.

— 1975 "Why Clams have the Shape They have: An Experimental Analysis of Burrowing." Paleobiology 1: 48-58.

Stehli, Frank G. 1964. "Permian Zoogeography and Its Bearing on Climate." A. E. M. Nairn (ed.), Problems in Paleoclimatology. London: Interscience Publications, pp. 537-549.

Stockton, William L. and Cowen, Richard. 1976. "Stereoscopic Vision in One Eye: The Paleophysiology of the Schizochroal Eye of Trilobites." Paleobiology 2: 304-315.

Thomas, R. D. K. 1979. "Morphology, Constructional." Rhodes W Fairbridge, David Jablonski (eds.), The Encyclopedia of Paleontology. Stroudsburg (Pennsylvania):Dowden Hutchinson and Ross, pp. 482-487.

Thompson, D'Arcy W. 1917. On Growth and Form. Cambridge: Cambridge University Press [2nd ed., 1942].

Trueman, Arthur E. 1922. "The Use of Gryphaea in the Correlation of the Lower Lias." Geological Magazine 59: 256-268.

Valentine, James W. 1973. Evolutionary Paleoecology of the Marine Biosphere. Englewood Cliffs: Prentice-Hall.

Vogel, Klaus. 1960. "Zur Struktur und Funktion der 'Siphonalpfeiler' der Hippuriten (Lamellibranchiata)." Paläontologische Zeitschrift 34: 275-294.

1966 "Ein funktionsmorphologische Studie an der Brachiopoden-Gattung Pygope (Malm bis Unterkreide)." Neues Jahrbuch der Geologie und Paläontologie, Abhandlungen 125: 423-442.

Williams, Alwyn. 1953. "The Morphology and Classification of the Oldhaminoid Brachiopods." Journal of the Washington Academy of Science 43: 279-287. 